\title{
Metabolic engineering of Corynebacterium glutamicum for efficient production of succinate from lignocellulosic hydrolysate
}

Yufeng Mao ${ }^{1 \dagger}$, Guiying $\mathrm{Li}^{1 \dagger}$, Zhishuai Chang ${ }^{1 \dagger}$, Ran Tao ${ }^{1}$, Zhenzhen Cui ${ }^{1}$, Zhiwen Wang ${ }^{1 *}$, Ya-jie Tang ${ }^{2}$, Tao Chen ${ }^{1 *}$ and Xueming Zhao ${ }^{1}$

\begin{abstract}
Background: Succinate has been recognized as one of the most important bio-based building block chemicals due to its numerous potential applications. However, efficient methods for the production of succinate from lignocellulosic feedstock were rarely reported. Nevertheless, Corynebacterium glutamicum was engineered to efficiently produce succinate from glucose in our previous study.

Results: In this work, C. glutamicum was engineered for efficient succinate production from lignocellulosic hydrolysate. First, xylose utilization of C. glutamicum was optimized by heterologous expression of $x y / A$ and $x y / B$ genes from different sources. Next, $x y \mid A$ and $x y \mid B$ from Xanthomonas campestris were selected among four candidates to accelerate xylose consumption and cell growth. Subsequently, the optimal $x y \mid A$ and $x y \mid B$ were co-expressed in C. glutamicum strain SAZ3 ( $\triangle / d h A \triangle p t a \triangle p q o \Delta c a t P_{\text {sod }}-p p c P_{\text {sod }}-$ pyc) along with genes encoding pyruvate carboxylase, citrate synthase, and a succinate exporter to achieve succinate production from xylose in a two-stage fermentation process. Xylose utilization and succinate production were further improved by overexpressing the endogenous tkt and tal genes and introducing araE from Bacillus subtilis. The final strain C. glutamicum CGS5 showed an excellent ability to produce succinate in two-stage fermentations by co-utilizing a glucose-xylose mixture under anaerobic conditions. A succinate titer of $98.6 \mathrm{~g} \mathrm{~L}^{-1}$ was produced from corn stalk hydrolysate with a yield of $0.87 \mathrm{~g} / \mathrm{g}$ total substrates and a productivity of $4.29 \mathrm{~g} \mathrm{~L}^{-1} \mathrm{~h}^{-1}$ during the anaerobic stage.
\end{abstract}

Conclusion: This work introduces an efficient process for the bioconversion of biomass into succinate using a thoroughly engineered strain of C. glutamicum. To the best of our knowledge, this is the highest titer of succinate produced from non-food lignocellulosic feedstock, which highlights that the biosafety level 1 microorganism C. glutamicum is a promising platform for the envisioned lignocellulosic biorefinery.

Keywords: Corynebacterium glutamicum, Succinate, Xylose, Lignocellulosic hydrolysate

\footnotetext{
*Correspondence: zww@tju.edu.cn; chentao@tju.edu.cn

${ }^{\dagger}$ Yufeng Mao, Guiying Li, and Zhishuai Chang contributed equally to this work

1 Key Laboratory of Systems Bioengineering (Ministry of Education),

SynBio Research Platform, Collaborative Innovation Center of Chemical

Science and Engineering (Tianjin), School of Chemical Engineering

and Technology, Tianjin University, Tianjin 300072, China

Full list of author information is available at the end of the article
}

(c) The Author(s) 2018. This article is distributed under the terms of the Creative Commons Attribution 4.0 International License (http://creativecommons.org/licenses/by/4.0/), which permits unrestricted use, distribution, and reproduction in any medium, provided you give appropriate credit to the original author(s) and the source, provide a link to the Creative Commons license, and indicate if changes were made. The Creative Commons Public Domain Dedication waiver (http://creativecommons.org/ publicdomain/zero/1.0/) applies to the data made available in this article, unless otherwise stated. 


\section{Background}

In 2004, the US Department of Energy (DOE) designated succinate as one of the 12 most promising bio-based platform chemicals [1]. Succinate and its derivatives have extensive applications in the chemical, food, agricultural, and plastics industries [2]. The demand for this valuable building block is expected to rapidly increase to 700000 tons per year by 2020 [3]. As reviewed by Ahn et al. [4], great advances have been made in the development of metabolically engineered microorganisms capable of efficiently producing succinate on an industrial scale. Corynebacterium glutamicum S071/pGEX4NCgl0275 was even able to produce $152.2 \mathrm{~g} \mathrm{~L}^{-1}$ succinate from glucose [5], which is the highest succinate titer ever reported. Moreover, wild-type Actinobacillus succinogenes ATCC55618 was reported to be able to produce $151.44 \mathrm{~g} \mathrm{~L}^{-1}$ succinate from fresh cassava root [6]. However, studies of succinate production over the last decade have focused on the use of purified sugars or food-based feedstocks, which cannot be used industrially. There also seem to be few reports on the efficient production of succinate from non-food lignocellulosic feedstocks, such as corn stalk, sugarcane bagasse, pine-, oak-, or spruce wood. Nevertheless, some representative studies with good performance do exist. For example, $11.13 \mathrm{~g} \mathrm{~L}^{-1}$ of succinate was produced from corn stalk hydrolysate with a high yield of $1.02 \mathrm{~g} / \mathrm{g}$ total sugars using $E$. coli BA204 [7]. The strain E. coli SD121 was able to produce $57.8 \mathrm{~g} \mathrm{~L}^{-1}$ succinate from corn stalk hydrolysate with a yield of $0.87 \mathrm{~g} / \mathrm{g}$ total sugars [8]. Moreover, A. succinogenes NJ113 was able to produce $70.3 \mathrm{~g} \mathrm{~L}^{-1}$ of succinate from corn fiber hydrolysate with a yield of $0.68 \mathrm{~g} \mathrm{~g}^{-1}$ total sugars [9]. Up to now, the highest succinate titer from non-food lignocellulosic hydrolysate was produced from sugarcane bagasse hydrolysate using E. coli BA305, which reached $83 \mathrm{~g} \mathrm{~L}^{-1}$ by summing up the titers of three repetitive fermentations [10]. However, the process of cell recycling is complicated and costly. In most reports on succinate production from lignocellulosic biomass, the yields were quite good, but the titers were generally limited by the sugar concentration obtained from the hydrolysis of lignocellulosic biomass, making the process uneconomical for further separation and purification. Hydrolysis efficiency is, therefore, considered a key factor of process viability. Enzymatic hydrolysis combined with dilute acid pretreatment was utilized as the primary method for sugar production from lignocellulosic biomass. Corn stalk is an agricultural byproduct of annual renewable crops and is available in abundance around the world. In fact, it is estimated that approximately 230 million tons of lignocellulosic corn stalks are produced each year [11]. Corn stalk biomass is, therefore, a potential feedstock for biorefineries in China. In this study, corn stalk hydrolysates containing high concentrations of glucose and xylose obtained by means of enzymatic hydrolysis were chosen as substrate for succinate production.

Corynebacterium glutamicum, a facultatively anaerobic Gram-positive soil bacterium with GRAS (generally regarded as safe) status, is one of the major succinate producing organisms [2, 12]. Under oxygen deprivation, energy and carbon will primarily be channeled towards product formation rather than growth in $C$. glutamicum [13]. A series of metabolically engineered C. glutamicum strains were constructed for the efficient production of succinate from glucose under anaerobic conditions [5, 13-17]. The succinate production processes that utilize C. glutamicum were mainly based on glucose from starch. Strain NC-2, with an $l d h A$ deletion and the introduction of $x y l A$ and $x y l B$ genes from $E$. coli, produced $40.8 \mathrm{~g} / \mathrm{L}$ of succinate in $48 \mathrm{~h}$ from corn cob hydrolysate with a yield of $0.69 \mathrm{~g} \mathrm{~g}^{-1}$ total sugar under anaerobic conditions [18]. However, the titer and yield were relatively low and still not satisfactory.

Xylose utilization is considered a cornerstone of the efficient utilization of lignocellulosic biomass. Because of the lack of a xylose isomerase (XI) pathway, C. glutamicum could not use xylose as the carbon source before xylose isomerase from $E$. coli was introduced [19]. Since then, a variety of metabolic engineering strategies have been studied and applied to improve xylose utilization. These include multiple chromosomally integrated copies of the $x y l A B$ operon [20], expression optimization of assimilation pathways [21, 22], selection of xylose isomerase and xylulokinase [23], introduction of a heterogenous xylose transporter [24-27], and overexpression of a non-oxidative pentose phosphate pathway (PPP) to increase the flux through the xylose metabolism [28]. Radek et al. [29] engineered a C. glutamicum strain showing more carbon efficiency but a lower growth rate, by converting xylose into $\alpha$-ketoglutarate via the Weimberg pathway, which was beneficial for succinate yields under aerobic conditions [30]. However, the XI pathway was still the main pathway used in succinate production from xylose under anaerobic conditions.

In the present study, several strategies were taken into account to improve xylose utilization in C. glutamicum. The engineered C. glutamicum SAZ3 was selected as the chassis for succinate production. The final engineered strain CGS5 (Fig. 1) could simultaneously and completely consume sugar mixtures comprising glucose and xylose under anaerobic conditions. Using enzymatic hydrolysate of corn straw, it produced $98.6 \mathrm{~g} \mathrm{~L}^{-1}$ succinate with a yield of $0.87 \mathrm{~g} \mathrm{~g}^{-1}$ total substrates in the anaerobic stage. These are the highest titers obtained with non-food lignocellulosic hydrolysate as the substrate to date. 


\section{(See figure on next page.)}

Fig. 1 Succinate biosynthesis pathway of C. glutamicum. The bold black arrows indicate metabolic fluxes increased by overexpression or introduction of the corresponding genes. The gray arrows indicate the reactions leading to a byproduct or presumably irrelevant reactions. Deleted genes are indicated with crosses. Metabolites: G6P glucose-6-phosphate, 6PGL 6-phosphoglucono-1,5-lactone, 6PG 6-phosphogluconate, Ru5P ribulose-5-phosphate, Xu5P xylulose-5-phosphate, R5P ribose-5-phosphate, G3P glyceraldehyde-3-phosphate, S7P sedoheptulose-7-phosphate, F6P fructose-6-phosphate, FBP fructose-1,6-bisphosphate, E4P erythrose-4-phosphate, DHAP dihydroxyacetone, DPG glycerate-1,3-diphosphate, 3PG glycerate-3-phosphate, 2PG glycerate-2-phosphate, PEP phosphoenolpyruvate, PYR pyruvate, AcP acetyl phosphate, AcCoA acetyl-CoA. Genes and their encoded enzymes: iolT encoding myo-inositol permease, glk encoding glucokinase, pts $G$ encoding glucose-Ell of phosphoenolpyruvate phosphotransferase system (PTS), pgi encoding glucose-6-phosphate isomerase, araE encoding a $\mathrm{H}^{+}$symporter protein, $x y / A$ encoding xylose isomerase, $x y \mid B$ encoding xylulokinase, zWf and opcA encoding glucose-6-phosphate dehydrogenase, devB encoding 6-phosphogluconolactonase, gnd encoding 6-phosphogluconate dehydrogenase, tkt encoding transketolase, tal encoding transaldolase, pqo encoding pyruvate: quinone oxidoreductase, pta encoding phosphotransacetylase, ackA encoding acetate kinase, cat encoding acetyl-CoA:CoA transferase, aceE encoding pyruvate complex dehydrogenase E1 component, ppc encoding phosphoenolpyruvate carboxylase, pyc encoding pyruvate carboxylase, $m d h$ encoding malate dehydrogenase, $g / t A$ encoding citrate synthase, sucE encoding succinate exporter

\section{Methods}

\section{Strains and media}

All the strains used in this study are listed in Table 1. Escherichia coli DH5 $\alpha$ (Invitrogen) was used for routine cloning and maintenance of plasmids. The succinateproducing C. glutamicum strain SAZ3 [31], with deletions of $l d h A, p q o, c a t$, and $p t a$, and replacement of the native promoters of $p y c$ and $p p c$ with the sod promoter $\left(\Delta l d h A \Delta p t a \Delta p q o \Delta c a t \mathrm{P}_{\text {sod }}-p p c \mathrm{P}_{\text {sod }}-p y c\right)$, was used as host strain.

Brain heart infusion sorbitol (BHIS) medium was used for transformation of C. glutamicum. Lysogeny broth (LB) containing tryptone $10 \mathrm{~g} \mathrm{~L}^{-1}$, yeast extract $5 \mathrm{~g} \mathrm{~L}^{-1}$, and $\mathrm{NaCl} 10 \mathrm{~g} \mathrm{~L}^{-1}$ was used for cultivation of $E$. coli DH5 $\alpha$. The modified CGIII complex medium ( $\mathrm{pH} 7.4$ ) containing tryptone $10 \mathrm{~g} \mathrm{~L}^{-1}$, yeast extract $10 \mathrm{~g} \mathrm{~L}^{-1}$, and 3-morpholinopropanesulfonic acid (MOPS) $21 \mathrm{~g} \mathrm{~L}^{-1}$ with $20 \mathrm{~g} \mathrm{~L}^{-1}$ glucose was used for precultures of C. glutamicum [31]. CGXIIA medium ( $\mathrm{pH} 7.0$ ), containing $\left(\mathrm{NH}_{4}\right)_{2} \mathrm{SO}_{4} 20 \mathrm{~g} \mathrm{~L}^{-1}$, urea $5 \mathrm{~g} \mathrm{~L}^{-1}, \mathrm{KH}_{2} \mathrm{PO}_{4} 1 \mathrm{~g} \mathrm{~L}^{-1}, \mathrm{~K}_{2} \mathrm{HPO}_{4} 1 \mathrm{~g} \mathrm{~L}^{-1}, \mathrm{MgSO}_{4} \cdot 7 \mathrm{H}_{2} \mathrm{O}$ $0.25 \mathrm{~g} \mathrm{~L}^{-1}, \mathrm{CaCl}_{2} 10 \mathrm{mg} \mathrm{L}^{-1}, \mathrm{FeSO}_{4} \cdot 7 \mathrm{H}_{2} \mathrm{O} 10 \mathrm{mg} \mathrm{L}^{-1}$, $\mathrm{MnSO}_{4} \cdot \mathrm{H}_{2} \mathrm{O} \quad 0.1 \mathrm{mg} \mathrm{L} \mathrm{L}^{-1}, \mathrm{ZnSO}_{4} \cdot 7 \mathrm{H}_{2} \mathrm{O} 1 \mathrm{mg} \mathrm{L}^{-1}$, $\mathrm{CuSO}_{4} \cdot 5 \mathrm{H}_{2} \mathrm{O} 0.2 \mathrm{mg} \mathrm{L}{ }^{-1}, \mathrm{NiCl}_{2} \cdot 6 \mathrm{H}_{2} \mathrm{O} 20 \mu \mathrm{g} \mathrm{L} \mathrm{L}^{-1}$, biotin (Sangon Biotech, Shanghai, China) $0.2 \mathrm{mg} \mathrm{L}^{-1}$, and MOPS $21 \mathrm{~g} \mathrm{~L}^{-1}$ with the indicated amounts of glucose (named CGXIIA-G) or xylose (named CGXIIA-X) was used during the aerobic stage. CGXIIB medium ( $\mathrm{pH} 7.0$ ), containing $\left(\mathrm{NH}_{4}\right)_{2} \mathrm{SO}_{4} 5 \mathrm{~g} \mathrm{~L}^{-1}$, urea $5 \mathrm{~g} \mathrm{~L}^{-1}, \mathrm{KH}_{2} \mathrm{PO}_{4}$ $1 \mathrm{~g} \mathrm{~L}^{-1}, \mathrm{~K}_{2} \mathrm{HPO}_{4} 1 \mathrm{~g} \mathrm{~L}^{-1}, \mathrm{MgSO}_{4} \cdot 7 \mathrm{H}_{2} \mathrm{O} 0.25 \mathrm{~g} \mathrm{~L}^{-1}$, $\mathrm{CaCl}_{2} 10 \mathrm{mg} \mathrm{L}^{-1}, \mathrm{FeSO}_{4} \cdot 7 \mathrm{H}_{2} \mathrm{O} 10 \mathrm{mg} \mathrm{L}{ }^{-1}, \mathrm{MnSO}_{4} \cdot \mathrm{H}_{2} \mathrm{O}$ $0.1 \mathrm{mg} \mathrm{L}{ }^{-1}, \mathrm{ZnSO}_{4} \cdot 7 \mathrm{H}_{2} \mathrm{O} 1 \mathrm{mg} \mathrm{L} \mathrm{L}^{-1}, \mathrm{CuSO}_{4} \cdot 5 \mathrm{H}_{2} \mathrm{O}$ $0.2 \mathrm{mg} \mathrm{L}^{-1}, \mathrm{NiCl}_{2} \cdot 6 \mathrm{H}_{2} \mathrm{O} 20 \mu \mathrm{g} \mathrm{L}^{-1}$, and biotin $0.2 \mathrm{mg} \mathrm{L}^{-1}$ with the indicated amounts of glucose and/or xylose was used as medium for succinate production during the anaerobic stage. Antibiotics were added to the media at the following concentrations when required: $50 \mu \mathrm{g}$ kanamycin $\mathrm{mL}^{-1}$ and $6 \mu \mathrm{g}$ chloramphenicol $\mathrm{mL}^{-1}$ for E. coli,
$25 \mu \mathrm{g}$ kanamycin $\mathrm{mL}^{-1}$ and $10 \mu \mathrm{g}$ chloramphenicol $\mathrm{mL}^{-1}$ for C. glutamicum. Antibiotics and other chemicals used in this study were purchased from Sangon Biotech (Sangon Biotech, Shanghai, China). Corn stalk hydrolysate was obtained from HEBABIZ Pharmaceutical Co. Ltd., China. Before using as substrate for succinate production, the hydrolysate was sterilized at $115^{\circ} \mathrm{C}$ for $10 \mathrm{~min}$.

\section{Construction of plasmids and strains}

All the strains and plasmids used in this study are listed in Table 1. All the primers used in this study are listed in Additional file 1: Table S1.

For the heterologous expression of genes encoding xylose isomerase $(x y l A)$ and xylulokinase $(x y l B)$ from Escherichia coli MG1655, Paenibacillus polymyxa SC2, Streptomyces coelicolor, and Xanthomonas campestris 8004, the plasmids pX-ecoAB, pX-ppmAB, pX-scoAB, and $\mathrm{pX}-\mathrm{xcbAB}$ were constructed, respectively.

For the construction of plasmid pX-ecoAB, the $x y l A$ and $x y l B$ genes were amplified from genomic DNA of $E$. coli MG1655 by PCR using the primer pair ecoxylAB-1/ ecoxylAB-2. The resulting fragment was digested with HindIII and XbaI, and ligated into pXMJ19 cut with the same enzymes. The plasmid $\mathrm{pX}-\mathrm{ppmAB}$ was constructed analogously, using $X b a \mathrm{I}$ and KpnI.

For the construction of plasmid $\mathrm{pX}-\mathrm{xcbAB}$, the $x y l A$ and $x y l B$ genes were amplified from genomic DNA of $X$. campestris by PCR using the primer pairs xcbxylA-1/ xcbxylA-2 and xcbxylB-1/xcbxylB-2, respectively. The two PCR products were spliced using the primer pair xcbxylA1/xcbxylB2, and the resulting fused PCR product was digested with HindIII and XbaI, and ligated into pXMJ19 cut with the same enzymes. The plasmid pXscoAB was constructed analogously, using Pst I and KpnI.

The replacement of the native promoter of tal by the strong sod promoter in the recombinant strain SAZ3 was achieved via a two-step homologous recombination procedure using the suicide vector $\mathrm{pDsacB}$. The flanking 


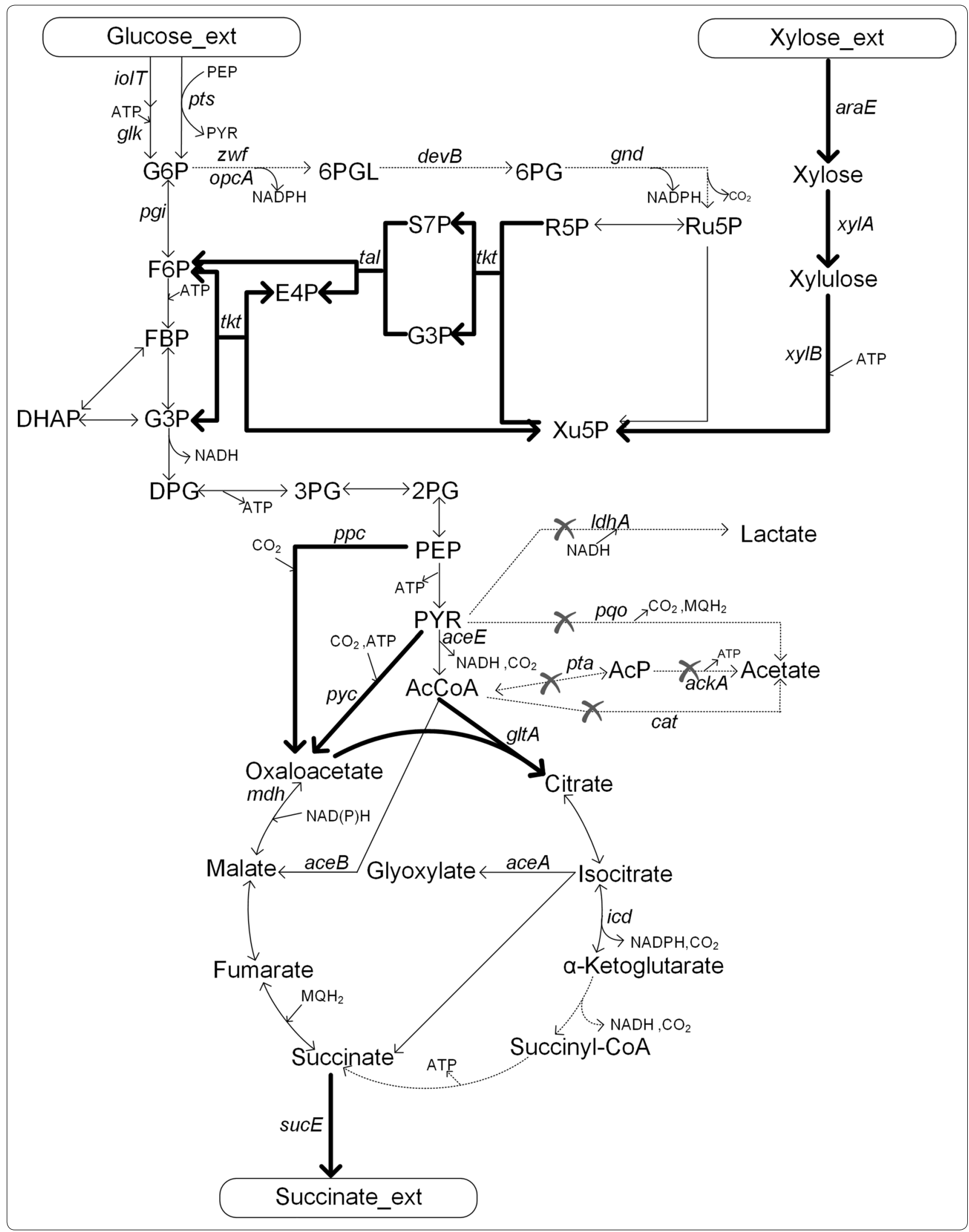


Table 1 Strains and plasmids used in this study

\begin{tabular}{|c|c|c|}
\hline Strain/plasmid & Relevant characteristics & References \\
\hline ATCC 13032 & C. glutamicum wild-type biotin auxotrophic & ATCC \\
\hline I-pXMJ19 & ATCC13032 (pXMJ19) & This study \\
\hline I-eco & ATCC13032 (pX-ecoAB) & This study \\
\hline I-sco & ATCC13032 (pX-scoAB) & This study \\
\hline I-ppm & ATCC13032 (pX-ppmAB) & This study \\
\hline $1-x c b$ & ATCC13032 (pX-xcbAB) & This study \\
\hline SAZ3 & ATCC13032 $\Delta$ ldh $\triangle a c k A-p t a \Delta p q o \Delta c a t P_{\text {sod }}$ pyc $P_{\text {sod }}$ ppc & Lab stock \\
\hline CGS1 & SAZ3; pX-xcbAB, pEpycgltAsucE & This study \\
\hline CGS2 & ATCC13032 $\Delta / d h \triangle a c k A-p t a \Delta p q o \Delta c a t P_{\text {sod }} p y c P_{\text {sod }} p p c P_{\text {sod }}$ tal $P_{\text {sod }}$ tkt & This study \\
\hline CGS3 & CGS2; pX-xcbAB, pEpycgltAsucE & This study \\
\hline CGS4 & ATCC13032 $\Delta l d h \triangle a c k A-p t a \Delta p q o \Delta c a t P_{\text {sod }} p y c P_{\text {sod }} p p c P_{\text {sod }}$ tal $P_{\text {sod }}$ tkt $P_{\text {tuf }}$ araE & This study \\
\hline CGS5 & CGS4; pX-xcbAB, pEpycgltAsucE & This study \\
\hline \multicolumn{3}{|l|}{ Plasmids } \\
\hline pDsacB & $\operatorname{Kan}^{\mathrm{R}}$; vector for in-frame deletion ( $\operatorname{sac}_{\text {B.subi }}$ lacZa; OriV $\left.E_{E .}\right)$ & Lab stock \\
\hline pD-ldh & pDsacB carrying the flanking sequences of the $/ d h$ gene & This study \\
\hline PD-PSL & pDsacB carrying the sod promoter, upstream and initial sequences of the tal gene & This study \\
\hline pD-PSK & pDsacB carrying the sod promoter, upstream and initial sequences of the $t k t$ gene & This study \\
\hline pD-P tufaraE & pDsacB carrying araE from B. subtilis 168 under the control of $P_{\text {tufi }}$ the flanking sequences of the Idh gene & This study \\
\hline pXMJ19 & 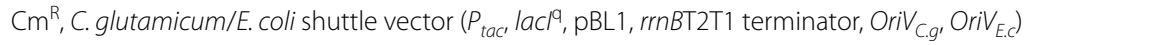 & Lab stock \\
\hline $\mathrm{pX}$-ecoAB & Derived from pXMJ19, for the overexpression of xyIAB from E. coli MG1655 & This study \\
\hline$p X-s c o A B$ & Derived from pXMJ19, for the overexpression of xyIAB from Streptomyces coelicolor & This study \\
\hline pX-ppmAB & Derived from pXMJ19, for the overexpression of xylAB from Paenibacillus polymyxa & This study \\
\hline $\mathrm{pX}-\mathrm{xcbAB}$ & Derived from pXMJ19, for the overexpression of xylAB from Xanthomonas campestris pv. campestris 8004 & This study \\
\hline pEC-XK99E & 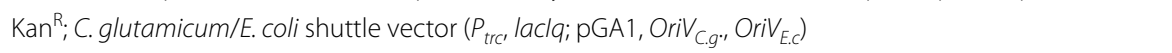 & Lab stock \\
\hline pEpycgltAsucE & Derived from pEC-XK99E, for the overexpression of pyc, gltA and sucE & Lab stock \\
\hline $\mathrm{pEP} 2$ & $\mathrm{Kan}^{\text {R}} ;$ C. glutamicum/E. coli shuttle vector, low copy & Lab stock \\
\hline pEP-P tufaraE & Derived from $\mathrm{pEP} 2$, for the overexpression of araE from B. subtilis 168 under the control of $P_{\text {tuf }}$ & This study \\
\hline
\end{tabular}

ATCC American type culture collection

sequences of the tal gene were amplified from genomic DNA of C. glutamicum using primer pairs PSL-1/ PSL-2 and PSL-3/PSL-4. The sod promoter region (192 bp upstream of the sod gene) was amplified from chromosomal DNA of C. glutamicum using the primer pair $\mathrm{P}_{\text {sod }}-1 / \mathrm{P}_{\text {sod }}-2$. The plasmid pD-PSL was assembled by circular polymerase extension cloning (CPEC) [32], using the overlap of the flanking sequences of the tal gene, $\mathrm{P}_{\text {sod }}$ and pDsacB cut with XbaI. The resulting plasmid pDPSL was used to transform SAZ3 by electroporation. The procedure of promoter replacement was carried out as described previously [14]. Subsequently, the native promoter of $t k t$ was analogously replaced by the strong sod promoter.

For the construction of the integrating plasmid $\mathrm{pD}$ ldh, the fragment ldhF upstream of the $l d h$ gene was first amplified from genomic DNA of C. glutamicum 13032 by PCR using the primer pair ldhF1/ldhF2. The PCR product was digested with EcoRI and SalI and ligated into pDsacB cut with the same enzymes. Similarly, the fragment $l d h B$ downstream of the $l d h$ gene was ligated into the plasmid containing $l d h F$ cut with SalI/HindIII.

For the construction of plasmid pEP-P tuf araE, the tuf promoter region (200 bp upstream of the tuf gene) was first amplified from chromosomal DNA of wild-type $C$. glutamicum using the primer pair $\mathrm{P}_{\text {tuf }}-1 / \mathrm{P}_{\text {tuf }}-2$. The PCR product was digested with $E c o$ RI and SalI and ligated into pEP2 cut with the same enzymes. Then, the 1.7-kb DNA fragment of the $a r a E$ gene was amplified from chromosomal DNA of B. subtilis 168 by PCR using the primer pair araE-1/araE-2. The PCR product was digested with $\mathrm{XbaI}$ and SalI and ligated into pEP-P $\mathrm{P}_{\text {tuf }}$ cut with the same enzymes.

Chromosomal integration of the xylose transporter gene araE was achieved using the plasmid $\mathrm{pD}-\mathrm{P}_{\text {tuf }}$ araE. The DNA fragment $\mathrm{P}_{\text {tuf }}$ araE was amplified from $\mathrm{pEP}$ $\mathrm{P}_{\text {tuf }}$ araE, in which the araE gene is under the control of the constitutive tuf promoter. The resulting plasmid pD- $\mathrm{P}_{\text {tuf }}$ araE was integrated into the genome of CGS2 by electroporation. 


\section{Culture conditions}

For the precultures of C. glutamicum, single colonies were grown in $5 \mathrm{~mL}$ of BHIS medium [33] at $30{ }^{\circ} \mathrm{C}$ and $220 \mathrm{rpm}$ overnight, after which the entire resulting culture was used to inoculate $50 \mathrm{~mL}$ of modified CGIII medium supplemented with $10 \mathrm{~g} \mathrm{~L}^{-1}$ of glucose, and grown to an $\mathrm{OD}_{600}$ of 10 .

For aerobic growth, cells were washed twice with CGXIIB medium and used to inoculate $50 \mathrm{ml}$ of CGXIIA medium with $20 \mathrm{~g} \mathrm{~L}^{-1}$ of xylose or glucose to an initial $\mathrm{OD}_{600}=0.8$, and cultured in $500 \mathrm{~mL}$ shake flasks at $30{ }^{\circ} \mathrm{C}$ and $220 \mathrm{rpm}$ on a rotary shaker.

A two-stage process was performed for succinate production. When the cultures reached an $\mathrm{OD}_{600}$ of 20, the cells were harvested by centrifugation (5 $000 \times g, 4{ }^{\circ} \mathrm{C}, 10 \mathrm{~min}$ ), washed with CGXIIB medium. An appropriate amount of washed cells was suspended in $25 \mathrm{~mL}$ CGXIIB medium with the indicated sugars and $200 \mathrm{mM}$ sodium bicarbonate, and the cell suspension was cultured in $50 \mathrm{~mL}$ serum bottles at $30{ }^{\circ} \mathrm{C}$ and $220 \mathrm{rpm}$ on a rotary shaker. To prevent acidification, $30 \mathrm{~g} \mathrm{~L}^{-1}$ of magnesium carbonate hydroxide $\left(4 \mathrm{MgCO}_{3} \cdot \mathrm{Mg}(\mathrm{OH})_{2} \cdot 5 \mathrm{H}_{2} \mathrm{O}\right)$ was added as a buffering agent. For induction, isopropyl $\beta$-D-1thiogalactopyranoside (IPTG; Sangon Biotech, China) was added to a final concentration of $1 \mathrm{mM}$. All the fermentation experiments were performed in triplicate.

\section{Analytical techniques}

Extracellular organic acids and pentoses were measured by HPLC [34]. Glucose was monitored using an SBA sensor machine (Institute of Microbiology, Shandong, China). Growth was determined by measuring the optical density at $600 \mathrm{~nm}\left(\mathrm{OD}_{600}\right)$. SDS-polyacrylamide gel electrophoretic (PAGE) analysis of intracellular proteins was conducted as previously described [35]. The specific growth rate was calculated as: $(\ln W 2-\ln W 1) /(t 2-t 1)$, where $W 1$ and $W 2$ are biomass at times $t 1$ and $t 2$. The sugar consumption rate was calculated as: $C_{t 1} / t 1$, where $C_{t 1}$ is the concentration of total consumed sugar at time $t 1$. Codon usage analysis was based on the Graphical codon usage analyzer v. 2.0 (http://gcua.schoedl.de/index .html).

\section{Real-time quantitative PCR (RT-qPCR)}

RT-qPCR was conducted as described previously [15]. After $3 \mathrm{~h}$ of anaerobic fermentation, the cells were harvested for RNA isolation. The $16 \mathrm{~S}$ rRNA gene was used as an internal reference for normalization. The primers used for RT-qPCR are listed in Additional file 1: Table S1. Samples were analyzed as previously described [31].

\section{Results and discussion}

Selection of optimal xylose isomerases and xylulokinases for heterologous expression

Heterologous expression of the XI pathway from E. coli endowed C. glutamicum with the ability to grow on xylose $[19,23]$. However, its xylose utilization capabilities were still unsatisfactory. Hence, selection of a better candidate pathway was carried out in this study. The $x y l A$ and $x y l B$ genes from E. coli MG1655, P. polymyxa SC2, $S$. coelicolor, and $X$. campestris 8004 (designations and sources are listed in Table 2) were cloned into the IPTGinducible expression vector $\mathrm{pXMJ19}$. The resulting plasmids pX-ecoAB, pX-ppmAB, pX-scoAB, and pX-xcbAB, were individually introduced into $C$. glutamicum ATCC 13032 along with pXMJ19 to generate the corresponding recombinant strains I-eco, I-ppm, I-sco, I-xcb, and I-pXMJ19, respectively. The growth and xylose consumption of the strains are shown in Fig. 2a.

Owing to the lack of xylose isomerase, the control strain I-pXMJ19 could not grow on xylose, as expected. By contrast, all the recombinant strains with the XI pathway were able to grow on xylose as sole carbon source. Among them, strain I-xcb exhibited a markedly faster maximum specific growth rate $\left(0.224 \pm 0.003 \mathrm{~h}^{-1}\right)$ and average xylose consumption rate $\left(0.44 \mathrm{~g} \mathrm{~L}^{-1} \mathrm{~h}^{-1}\right.$, calculated at $30 \mathrm{~h}$ ) than the other three strains. This observation was in agreement with a previous report, in which the overexpression of $x y l A$ from $X$. campestris and the endogenous $x y l B$ endowed $C$. glutamicum with a fast growth rate $\left(0.199 \pm 0.009 \mathrm{~h}^{-1}\right)$ [23]. SDS-PAGE analysis of intracellular proteins showed that strain I-xcb had

Table 2 Codon usage analysis of $x y I A$ and $x y / B$ orthologs from different sources

\begin{tabular}{|c|c|c|c|c|c|}
\hline \multirow[t]{2}{*}{ Gene } & \multirow[t]{2}{*}{ Source } & \multirow{2}{*}{$\begin{array}{l}\text { Gene } \\
\text { symbol }\end{array}$} & \multirow{2}{*}{$\begin{array}{l}\text { Protein } \\
\text { size } \\
\text { (kDa) }\end{array}$} & \multicolumn{2}{|c|}{ Codon usage } \\
\hline & & & & $\begin{array}{l}\text { Rarely } \\
\text { used } \\
\text { codons }\end{array}$ & $\begin{array}{l}\text { Very rarely } \\
\text { used codons }\end{array}$ \\
\hline \multirow[t]{4}{*}{$x y / A$} & E. coli & b3565 & 47.5 & 7 & 1 \\
\hline & P.polymyxa & $\begin{array}{l}\mathrm{PPSC}_{2} \\
\mathrm{C} 4572\end{array}$ & 52.2 & 7 & 2 \\
\hline & S. coelicolor & SCO1169 & 41.8 & 23 & 0 \\
\hline & $\begin{array}{l}\text { X. campes- } \\
\text { tris }\end{array}$ & XC_2477 & 49.2 & 5 & 0 \\
\hline \multirow[t]{4}{*}{$x y / B$} & E. coli & b3564 & 52.3 & 29 & 2 \\
\hline & P.polymyxa & $\begin{array}{l}\text { PPSC2_- } \\
\text { C4571 }\end{array}$ & 54.8 & 17 & 2 \\
\hline & S. coelicolor & SCO1170 & 51.9 & 26 & 0 \\
\hline & $\begin{array}{l}\text { X. campes- } \\
\text { tris }\end{array}$ & XC_2478 & 54.8 & 5 & 0 \\
\hline
\end{tabular}

'Very rarely used codons' and 'Rarely used codons' indicate codons represented at less than $10 \%$ or $20 \%$ in the codon usage table of C. glutamicum (http://www. kazusa.or.jp/codon/cgi-bin/showcodon.cgi?species $=196627 \&$ aa $=1 \&$ style $=N$ ) 


\section{(See figure on next page.)}

Fig. 2 Batch cultivation of C. glutamicum I-pXMJ19 (squares), I-eco (diamonds), I-ppm (circles), I-sco (upward triangles), and I-xcb (downward triangles). a Profiles of cell growth (filled symbols) and xylose consumption (open symbols) under aerobic conditions. The strains were cultured in CGXIIA medium containing $20 \mathrm{~g} \mathrm{~L}^{-1}$ xylose in $500-\mathrm{mL}$ flasks at $30^{\circ} \mathrm{C}$ and $220 \mathrm{rpm}$ with an initial $\mathrm{OD}_{600}$ of 0.8 , and were induced with $0.5 \mathrm{mM}$ IPTG. b SDS-PAGE analysis of intracellular proteins extracted from I-eco, I-ppm, I-sco and I-xcb from cultures with an $\mathrm{OD}_{600}$ of 5 . Proteins were separated on a 12\% SDS-PAGE gel. c Profiles of xylose consumption (open symbols) under anaerobic conditions with an initial $\mathrm{OD}_{600} \mathrm{Of} 30.30 \mathrm{~g} \mathrm{~L}^{-1}$ $4 \mathrm{MgCO}_{3} \cdot \mathrm{Mg}(\mathrm{OH})_{2} \cdot 5 \mathrm{H}_{2} \mathrm{O}, 200 \mathrm{mM}$ sodium bicarbonate and $1 \mathrm{mM}$ IPTG were added into the CGXIIB medium

the highest protein expression of xylose isomerase and xylulokinase (Fig. 2b). Furthermore, codon usage analysis revealed that $x y l A B$ from $X$. campestris has the most similar codon usage to that of C. glutamicum (Table 2), which might be the main reason for the observed high protein expression level.

In view of the different profiles of aerobic and anaerobic metabolism, the xylose utilization of strains I-eco, I-ppm, I-sco, and I-xcb was also evaluated under anaerobic conditions (Fig. 2c). Similar with the results obtained under aerobic conditions, strain I-xcb exhibited a faster xylose consumption rate $\left(1.80 \mathrm{~g} \mathrm{~L}^{-1} \mathrm{~h}^{-1}\right.$, calculated at $\left.12 \mathrm{~h}\right)$ than the other three strains $\left(1.62 \mathrm{~g} \mathrm{~L}^{-1} \mathrm{~h}^{-1}\right.$ for strain I-eco, $0.57 \mathrm{~g} \mathrm{~L}^{-1} \mathrm{~h}^{-1}$ for strain I-ppm and $0.65 \mathrm{~g} \mathrm{~L}^{-1} \mathrm{~h}^{-1}$ for strain I-sco).

It has been proved that overexpression of pyruvate carboxylase (pyc), citrate synthase $(g l t A)$, and succinate exporter (sucE) could efficiently improve succinate production in C. glutamicum [15], and therefore, plasmid pEpycgltAsucE (overexpressing pyc, gltA, and sucE genes) was introduced into SAZ3 $\left(\Delta l d h A \Delta p t a \Delta p q o \Delta c a t \mathrm{P}_{\text {sod }^{-}}\right.$ $\left.p p c \mathrm{P}_{\text {sod }}-p y c\right)$ along with the plasmid $\mathrm{pX}$-xcbAB. The resulting strain CGS1 was further tested for succinate production.

\section{Effect of the carbon source used during the two-stage fermentation on succinate production}

The carbon source influences gene expression of metabolic networks and, consequently, affects succinate production during the fermentation. It has been proven that the succinate yield from xylose is significantly higher than from glucose (25\% versus $14 \%$ ) in C. glutamicum under anaerobic conditions [19], suggesting that xylose might be a better substrate for succinate production. However, it has been demonstrated that the supply of ATP from xylose metabolism is insufficient during anaerobic succinate production in E. coli [7], and glucose was recommended as a co-substrate to alleviate the observed ATP shortage [36]. Therefore, the effect of carbon source used during the anaerobic phase on succinate production was evaluated in CGS1.

First, we prepared seed cultures using glucose as carbon source (in CGXIIA-G seed medium) in the first stage, after which the seed cultures were collected for succinate production during the anaerobic stage in which glucose or xylose was used as substrate. As shown in Table 3, the deletion of $l d h$ completely abolished lactate accumulation in CGS1. Notably, as the substrate used in the second stage, xylose was clearly superior to glucose in both succinate titer (27.4 versus $24.6 \mathrm{~g} \mathrm{~L}^{-1}$ ) and yield $(0.90$ versus $\left.0.81 \mathrm{~g} \mathrm{~L}^{-1}\right)$. Compared with succinate production from glucose, we also observed a dramatic decrease of pyruvate accumulation (from 2.19 to $0.03 \mathrm{~g} \mathrm{~L}^{-1}$ ) when xylose was fermented. This is most likely due to the fact that the phosphotransferase system (PTS) was not used for xylose transport, which otherwise would form pyruvate. Since the major acetate synthetic pathways were abolished in CGS1, with the exception of pyruvate complex dehydrogenase E1 component (encoded by aceE) (Fig. 1), the acetate accumulation was limited to a relatively low level. There was no obvious difference in acetate production between glucose and xylose fermentation $(0.45$ versus $\left.0.46 \mathrm{~g} \mathrm{~L}^{-1}\right)$. Liu et al. [7] discovered that $E$. coli needs to alleviate an ATP shortage to enable cell growth under anaerobic conditions by acetate synthesis during xylose fermentation. However, the cell growth of C. glutamicum was arrested under oxygen deprivation [37], and the demand for ATP was, therefore, not as strong as that in $E$. coli, which might be the reason for the similar acetate accumulation. $\alpha$-Ketoglutarate, synthesized in the tricarboxylic acid cycle (TCA cycle), has been reported as a major by-product during succinate production in C. glutamicum $[5,14,15]$. It is worth mentioning that malate dehydrogenase (encoded by $m d h$ ) is almost equally active with NADH and NADPH as coenzyme, judging by their respective $K_{\text {cat }}$ values [38]. This means that NADPH produced from the accumulation of $\alpha$-ketoglutarate could also serve as an efficient source of reducing power for the production of succinate. Interestingly, $\alpha$-ketoglutarate accumulation during xylose fermentation was also $24.7 \%$ lower than during glucose fermentation (1.34 versus $\left.1.78 \mathrm{~g} \mathrm{~L}^{-1}\right)$. The reason for this remains unknown.

It is notable that the xylose consumption rate of strain CGS1 was $50.5 \%$ lower than its glucose consumption rate during the second stage (1.39 versus $2.75 \mathrm{~g} \mathrm{~L}^{-1} \mathrm{~h}^{-1}$, Table 3) when the seed cultures were prepared using glucose as substrate. Thus, to improve the xylose consumption rate under anaerobic conditions, xylose was used as substrate for the seed culture in CGXIIA-X medium, and its effect on succinate production and 


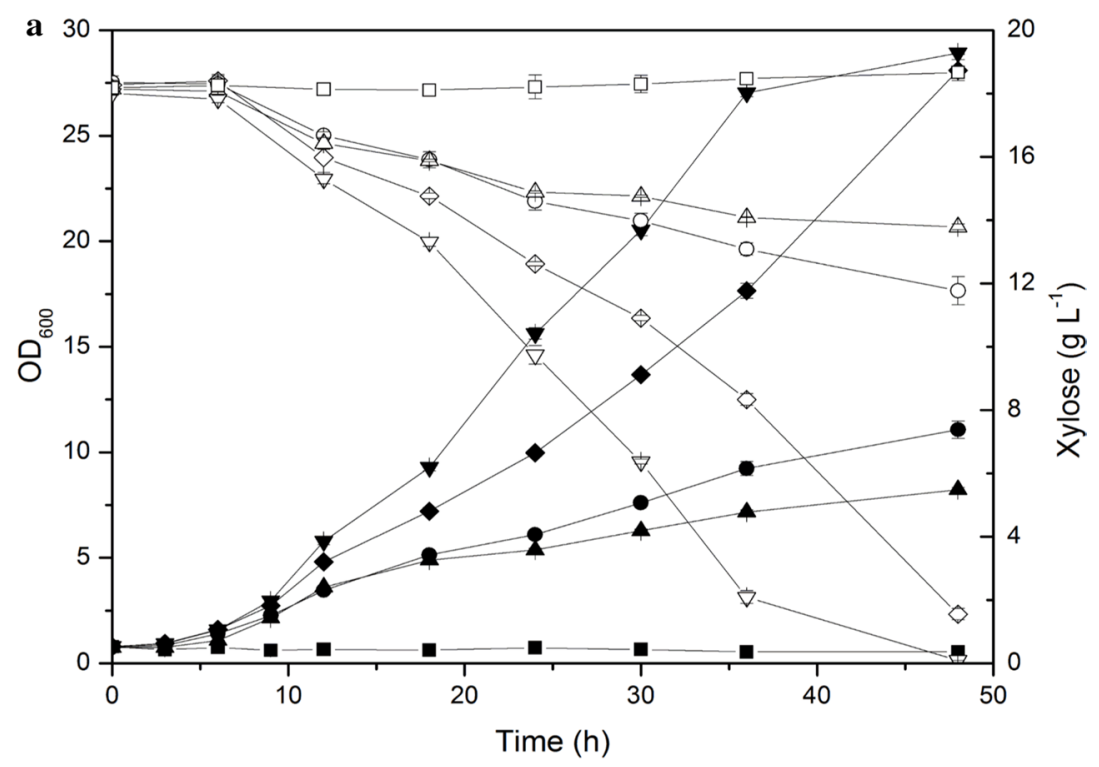

b $M$ I-eco I-ppm I-sco I-xcb
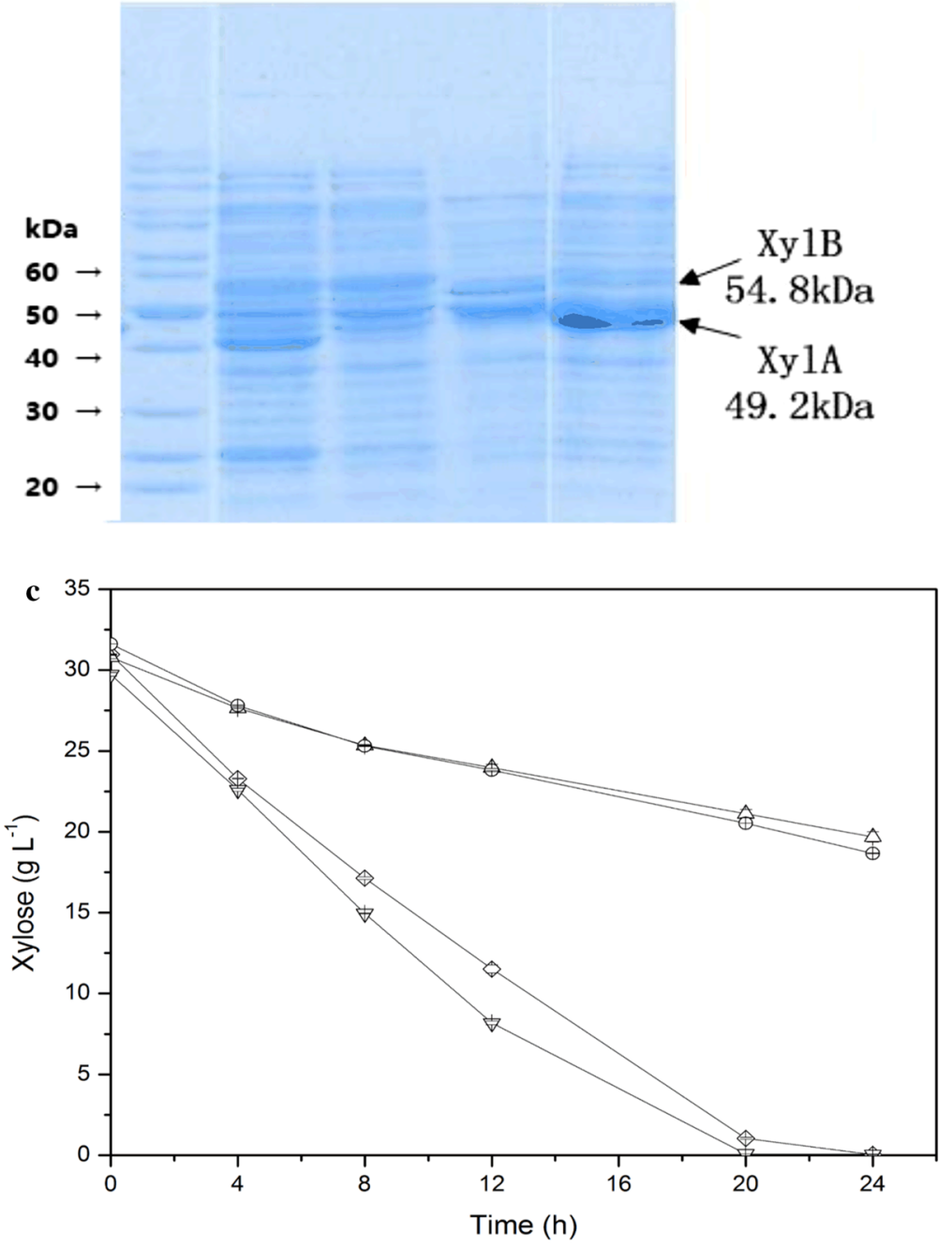


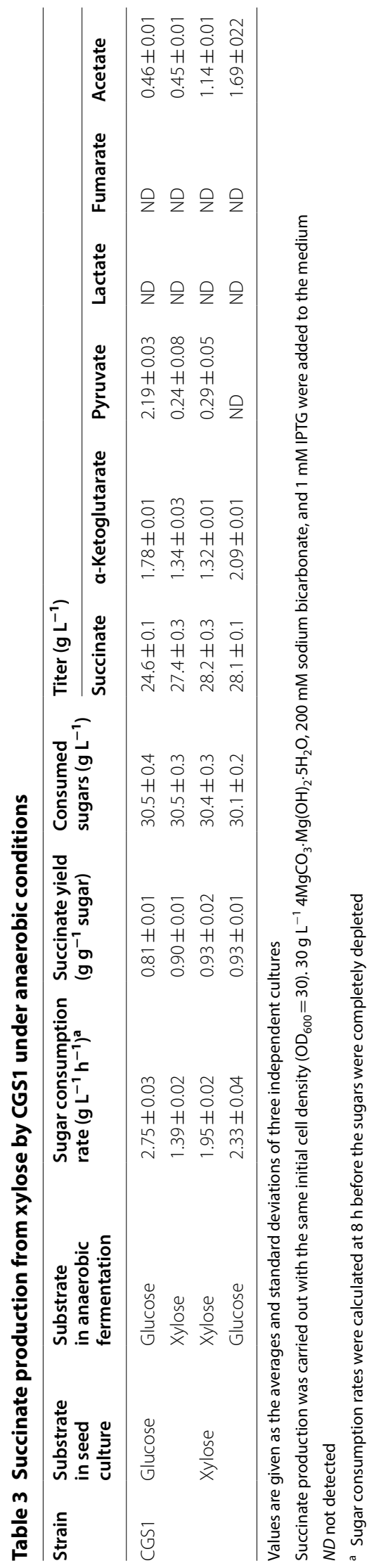




\section{(See figure on next page.)}

Fig. 3 Batch fermentation of C. glutamicum CGS1 (squares), CGS3 (circles) and CGS5 (upward triangles). a Profiles of cell growth (filled symbols) and xylose consumption (open symbols) in CGXIIA medium with $30 \mathrm{~g} \mathrm{~L}^{-1}$ xylose. b Profiles of succinate production (filled symbols) and xylose consumption (open symbols) under anaerobic conditions with an initial $\mathrm{OD}_{600}$ of $30.30 \mathrm{~g} \mathrm{~L}^{-1} 4 \mathrm{MgCO}_{3} \cdot \mathrm{Mg}(\mathrm{OH})_{2} \cdot 5 \mathrm{H}_{2} \mathrm{O}, 200 \mathrm{mM}$ sodium bicarbonate, and 1 mM IPTG were added into the CGXIIB medium. c Profiles of succinate yield (black bars), xylose consumption rate (white bars, calculated at $8 \mathrm{~h}$ ), and succinate productivity (grey bars, calculated at $8 \mathrm{~h}$ ) under anaerobic conditions

xylose utilization was evaluated. Perhaps, unsurprisingly, the xylose consumption rate of CGS1 in the second stage $\left(1.95 \mathrm{~g} \mathrm{~L}^{-1} \mathrm{~h}^{-1}\right)$ was improved by $40.3 \%$ when xylose was used for the seed culture, and a slight improvement of succinate yield was also observed ( 0.93 versus $0.90 \mathrm{~g} \mathrm{~g}^{-1}$ ). There was no obvious difference in the accumulation of $\alpha$-ketoglutarate and pyruvate in fermentations conducted with seed cultures from CGXIIA-G and CGXIIA$\mathrm{X}$ medium. However, CGS1 collected from CGXIIA-X medium produced a 1.5 -fold higher acetate concentration $\left(1.14 \mathrm{~g} \mathrm{~L}^{-1}\right)$ than when collected from CGXIIA-G medium $\left(0.45 \mathrm{~g} \mathrm{~L}^{-1}\right)$, which might be due to the aforementioned ATP shortage observed in aerobic seed cultures with xylose as carbon source.

To fully evaluate the effects of the carbon source, seed cultures from CGXIIA-X medium were also used for succinate production in the anaerobic stage with glucose as substrate. Compared to succinate production by seed cultures from CGXIIA-G medium, the glucose consumption rate of CGS1 collected from CGXIIA-X medium was decreased by $15.3 \%$ (2.33 versus $2.75 \mathrm{~g} \mathrm{~L}^{-1} \mathrm{~h}^{-1}$, Table 3 ). However, both the succinate titer $\left(28.1\right.$ versus $24.6 \mathrm{~g} \mathrm{~L}^{-1}$ ) and yield (0.93 versus $0.81 \mathrm{~g} \mathrm{~g}^{-1}$ ) were significantly improved.

As these results demonstrate, an effect of carbon source was inevitable during succinate production under oxygen deprivation, and xylose was preferable to glucose both during the aerobic and the anaerobic fermentation phase. As shown in Fig. 3b, c, CGS1 was able to produce succinate with a good yield $\left(0.93 \mathrm{~g} \mathrm{~g}^{-1} \mathrm{D}\right.$-xylose, $83 \%$ of the theoretical yield), while its productivity $\left(1.70 \mathrm{~g} \mathrm{~L}^{-1} \mathrm{~h}^{-1}\right.$ at $8 \mathrm{~h}$ ) was still not satisfactory. Hence, further genetic manipulations were carried out to improve the xylose utilization rate and succinate productivity.

\section{Improvement of xylose utilization and succinate production by the expression of $t k t, t a l$, and a xylose transporter}

It was reported that overexpression of $t k t$ (encoding transketolase) and tal (encoding transaldolase) increased the flux from the non-oxidative PPP into the glycolytic pathway, and improved the rate of xylose assimilation [39, 40]. Recently, Jo et al. [28] demonstrated that overexpression of tal in C. glutamicum could efficiently improve xylose utilization and succinate production during an aerobic fermentation process. Hence, to further facilitate xylose utilization, the strong constitutive promoter sod was inserted in front of $t k t$ and $t a l$ in strain SAZ3, yielding strain CGS2. The plasmid $\mathrm{pX}$-xcbAB was introduced into CGS2 along with pEpycgltAsucE to generate CGS3. Under anaerobic conditions, the transcriptional levels of tkt and tal in CGS3 were increased 13.08- and 5.77-fold, respectively, compared with strain CGS1.

As shown in Fig. 3a, CGS3 had an obvious growth advantage over CGS1 during aerobic xylose fermentation, which was consistent with a previous report [28]. During the anaerobic fermentation, overexpression of $t k t$ and tal also improved the xylose consumption rate by $12.3 \%$ ( 2.19 versus $1.95 \mathrm{~g} \mathrm{~L}^{-1} \mathrm{~h}^{-1}$ at $8 \mathrm{~h}$ ). Consequently, the succinate productivity increased from 1.70 to $1.85 \mathrm{~g} \mathrm{~L}^{-1} \mathrm{~h}^{-1}$. In addition, the yield of succinate was also slightly improved from 0.93 to $0.98 \mathrm{~g} \mathrm{~g}^{-1}$, reaching $88 \%$ of the theoretical yield.

Engineering of sugar transport was a driving force for efficient bioconversion of sugar mixtures derived from lignocellulose [41]. It is notable that the consumption rates of pentose sugars in C. glutamicum decreased appreciably at low sugar substrate concentrations [19, 42], which would encumber the whole fermentation process and cause a low production rate of succinate. To address this, the pentose transporter gene araE from Bacillus subtilis [43] was integrated into the chromosome of strain CGS2 at the ldh locus, yielding the strain CGS4. Subsequently, the plasmid pX-xcbAB was introduced into CGS4 along with pEpycgltAsucE to generate CGS5.

As expected, CGS5 showed a further improvement in growth under aerobic conditions (Fig. 3a). During the anaerobic fermentation, the yield of succinate remained at $0.98 \mathrm{~g} \mathrm{~g}^{-1}$, and the xylose consumption rate was slightly improved from 2.19 to $2.31 \mathrm{~g} \mathrm{~L}^{-1} \mathrm{~h}^{-1}$. Notably, the succinate production rate was significantly improved from 1.85 to $2.28 \mathrm{~g} \mathrm{~L}^{-1} \mathrm{~h}^{-1}$. The improvement of the succinate production rate was relatively higher than that of the xylose consumption rate. This was consistent with a previous report in which the recombinant strain CRXaraE showed 4.2-fold higher lactate productivity with a 2.7-fold higher xylose consumption rate after introducing araE from C. glutamicum ATCC 31831 [24].

\section{Succinate production from a mixture of glucose and xylose}

To evaluate the feasibility of anaerobic succinate production from different kinds of lignocellulosic biomass, 

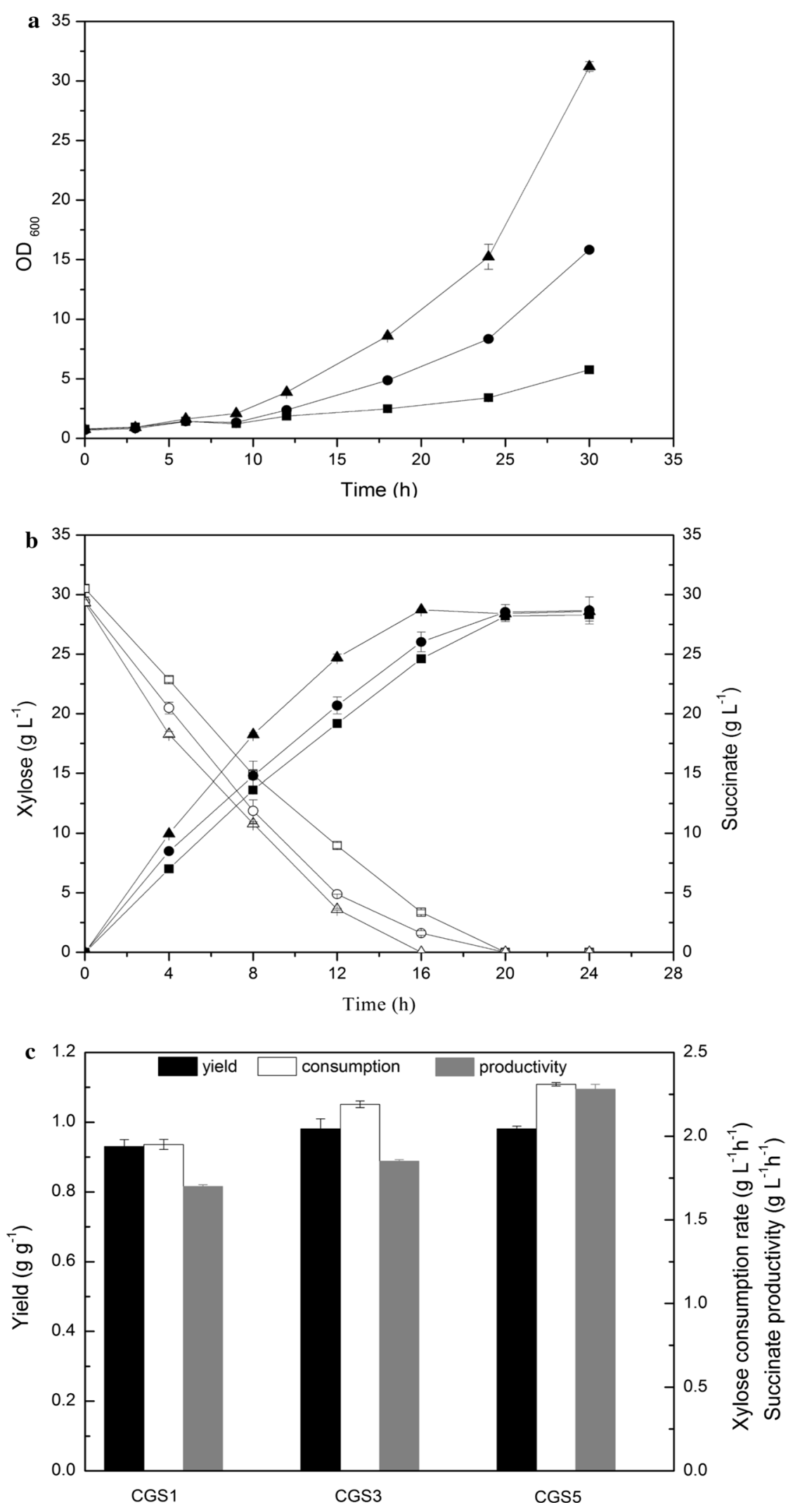
strain CGS5 was cultured in two-stage fermentations, and CGXIIB media with different ratios of glucose to xylose were used in the second stage. As shown in Table 4, there were no obvious differences in succinate titer and yield for the four sugar ratios. The yield of succinate reached very high levels, from 0.97 to $1.00 \mathrm{~g} \mathrm{~g}^{-1}$. The production of the major by-product $\alpha$-ketoglutarate varied with the sugar ratios, while the titer of acetate remained at $0.5 \mathrm{~g} \mathrm{~L}^{-1}$. The robustness of succinate production from the mixtures with different sugar ratios demonstrated that the engineered strain has great potential for the utilization of lignocellulosic hydrolysates of all kinds of biomass.

A high sugar concentration can lower the operating costs of industrial processes by reducing the time required for feeding and the risk of contamination. To test the strain's ability to produce succinate at high sugar concentrations, we used CGXIIB medium supplemented with $81.3 \mathrm{~g} \mathrm{~L}^{-1}$ glucose and $40.3 \mathrm{~g} \mathrm{~L}^{-1}$ xylose to culture CGS5 in the second stage. The ratio of glucose to xylose (2:1) was consistent with the glucose/xylose ratio of the most common lignocellulosic hydrolysate. As shown in Fig. 4a, CGS5 simultaneously and completely consumed glucose and xylose without significant carbon catabolite repression (CCR) under anaerobic conditions. $100.2 \mathrm{~g} \mathrm{~L}^{-1}$ succinate was accumulated within $23 \mathrm{~h}$, with a productivity of $4.35 \mathrm{~g} \mathrm{~L}^{-1} \mathrm{~h}^{-1}$. Okino et al. [13] observed that the succinate yield (about $1.45 \mathrm{~mol} /$ mol glucose) of C. glutamicum $\Delta$ ldhA-pCRA717 was not affected by the glucose concentration (from 20 to about $280 \mathrm{mM}$ ). Notably, when the glucose concentration was subsequently increased to $420 \mathrm{mM}\left(75.6 \mathrm{~g} \mathrm{~L}^{-1}\right)$, the succinate yield was decreased by about $15.2 \%$ to $1.23 \mathrm{~mol} /$ mol. Our results showed that the yield of succinate from a high-concentration sugar mixture $\left(121.6 \mathrm{~g} \mathrm{~L}^{-1}\right.$ total sugars) was $18.0 \%$ lower than that from a low-concentration mixture (31.7 $\mathrm{g} \mathrm{L}^{-1}$ total sugars) with the same glucose/ xylose ratio ( 0.82 versus $1.00 \mathrm{~g} / \mathrm{g}$ total sugars), which was consistent with the aforementioned report [13]. However, the loss of carbon yield can be attributed to the soaring accumulation of $\alpha$-ketoglutarate, since its titer increased from 1.24 to $16.2 \mathrm{~g} \mathrm{~L}^{-1}$ and its yield increased from 0.04 to $0.13 \mathrm{~g} \mathrm{~g}^{-1}$ total sugars, which means that the activity of the oxidative branch of the TCA cycle was also drastically increased. Because of the similar fermentation conditions, the residual oxygen in serum bottles could not answer for the variation of TCA activity. Even under strict anaerobic condition, a small but statistically significant flux through the oxidative part of the TCA cycle in wild-type C. glutamicum has been observed by bubbling $\mathrm{CO}_{2}$ instead of argon [44], which means that the activity of oxidative TCA arm does exist and can be activated under anaerobic conditions. This does make sense in view of the overall redox balance [44], but the reason for the variation of TCA activity is still unknown. In addition, acetate increased to $2.3 \mathrm{~g} \mathrm{~L}^{-1}$, but the acetate yield decreased, which suggested that the ATP demand was actually reduced at the higher sugar concentration. The concentration of fumarate reached $0.55 \mathrm{~g} \mathrm{~L}^{-1}$, while the concentrations of other organic acids were below $0.1 \mathrm{~g} \mathrm{~L}^{-1}$, which was negligible. However, the succinate yield of $0.82 \mathrm{~g} \mathrm{~g}^{-1}$ was still acceptable and was obtained alongside a titer of $100.2 \mathrm{~g} \mathrm{~L}^{-1}$.

\section{Efficient succinate production from lignocellulosic hydrolysate}

Under oxygen deprivation, C. glutamicum exhibits high tolerance to general lignocellulose-derived fermentation inhibitors [45]. However, inhibitors such as furfural, 5-hydroxymethylfurfural and vanillic had an inhibitory effect on glucose consumption and succinate accumulation under anaerobic conditions, and their mixtures

Table 4 Succinate production from sugar mixtures with different ratios of glucose to xylose by CGS5 under anaerobic conditions

\begin{tabular}{|c|c|c|c|c|c|c|c|c|c|}
\hline \multirow[t]{2}{*}{ Strain } & \multirow{2}{*}{$\begin{array}{l}\text { Succinate yield } \\
\text { (g/g total sugars) }\end{array}$} & \multicolumn{2}{|c|}{$\begin{array}{l}\text { Consumed sugars } \\
\left(\mathrm{g} \mathrm{L}^{-1}\right)\end{array}$} & \multicolumn{6}{|c|}{ Titer $\left(\mathrm{g} \mathrm{L}^{-1}\right)$} \\
\hline & & Glucose & Xylose & Succinate & a-Ketoglutarate & Pyruvate & Lactate & Fumarate & Acetate \\
\hline \multirow[t]{5}{*}{ CGS5 } & $0.98 \pm 0.01$ & 0 & $30.4 \pm 0.3$ & $29.7 \pm 0.1$ & $1.41 \pm 0.01$ & $0.31 \pm 0.01$ & ND & ND & $0.66 \pm 0.01$ \\
\hline & $0.98 \pm 0.03$ & $10.6 \pm 0.1$ & $21.1 \pm 0.2$ & $30.9 \pm 0.6$ & $1.04 \pm 0.36$ & $0.24 \pm 0.09$ & ND & ND & $0.65 \pm 0.02$ \\
\hline & $0.97 \pm 0.05$ & $15.7 \pm 0.3$ & $15.0 \pm 0.4$ & $29.7 \pm 0.9$ & $0.70 \pm 0.09$ & $0.19 \pm 0.04$ & ND & ND & $0.59 \pm 0.02$ \\
\hline & $1.00 \pm 0.03$ & $21.6 \pm 0.1$ & $10.1 \pm 0.1$ & $31.8 \pm 0.3$ & $1.24 \pm 0.06$ & $0.27 \pm 0.01$ & ND & ND & $0.63 \pm 0.01$ \\
\hline & $1.00 \pm 0.01$ & $31.5 \pm 0.1$ & 0 & $31.4 \pm 0.1$ & $0.80 \pm 0.02$ & $0.38 \pm 0.01$ & ND & ND & $0.52 \pm 0.01$ \\
\hline
\end{tabular}

Values are given as the averages and standard deviations of three independent cultures

Succinate production was carried out with the same initial cell density $\left(\mathrm{OD}_{600}=30\right) .30 \mathrm{~g} \mathrm{~L}^{-1} 4 \mathrm{MgCO}_{3} \cdot \mathrm{Mg}(\mathrm{OH})_{2} \cdot 5 \mathrm{H}_{2} \mathrm{O}, 200 \mathrm{mM}$ sodium bicarbonate, and $1 \mathrm{mM} \mathrm{IPTG}$ were added to the medium

ND not detected 

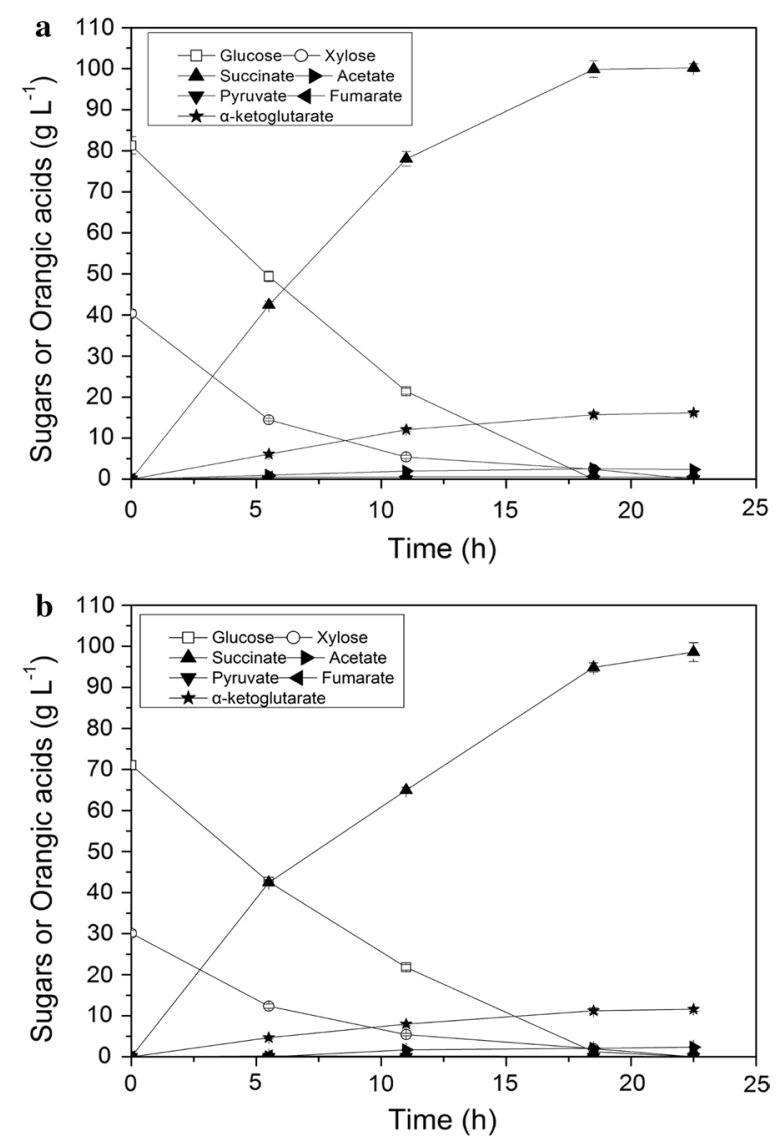

Fig. 4 Succinate production by CGS5 at high cell density $\left(O D_{600}=150\right)$ under anaerobic conditions. $100 \mathrm{~g} \mathrm{~L}^{-1}$

$4 \mathrm{MgCO}_{3} \cdot \mathrm{Mg}(\mathrm{OH})_{2} \cdot 5 \mathrm{H}_{2} \mathrm{O}, 300 \mathrm{mM}$ sodium bicarbonate, and $2 \mathrm{mM}$ IPTG were added into the CGXIIB medium. The consumption of glucose (open squares), xylose (open circles), and concentration of succinate (filled upward triangles), ketoglutarate (filled stars), pyruvate (filled downward triangles), fumarate (filled leftward triangles), and acetate (filled rightward triangles) are shown. a Profiles of the production of organic acids and consumption of sugars from mixtures of glucose and xylose. $\mathbf{b}$ Profiles of the production of organic acids and consumption of sugars from lignocellulosic hydrolysate

collocated as the actual diluted acid hydrolysate of corn cobs showed a more toxic effect on succinate production [46]. To avoid this problem, we used corn stalk hydrolysate with much less inhibitors, which was prepared using the most widely used commercial cellulolytic enzyme reagent Cellic ${ }^{\circledR} \mathrm{CTec} 2$ [47]. In the second stage, CGXIIB medium with diluted hydrolysate $\left(71.0 \mathrm{~g} \mathrm{~L}^{-1}\right.$ glucose and $30.1 \mathrm{~g} \mathrm{~L}^{-1}$ xylose) was used for succinate production.

There were no significant differences in the sugar utilization pattern between the fermentations with mixed sugars (Fig. 4a) and the hydrolysate (Fig. 4b), but the consumption rate of total sugars decreased by $16.8 \%$ (4.40 versus $5.29 \mathrm{~g} \mathrm{~L}^{-1} \mathrm{~h}^{-1}$ ). However, to our surprise, $98.6 \mathrm{~g} \mathrm{~L}^{-1}$ succinate was accumulated with a yield of $0.98 \mathrm{~g} / \mathrm{g}$ total sugars, which was $16.3 \%$ higher than the yield of $0.82 \mathrm{~g} / \mathrm{g}$ total sugars generated from the mixed sugars. The volumetric productivity of succinate from lignocellulosic hydrolysate was, therefore, comparable to that from sugar mixture (4.29 versus $4.35 \mathrm{~g} \mathrm{~L}^{-1} \mathrm{~h}^{-1}$ ). Likewise, $11.6 \mathrm{~g} \mathrm{~L}^{-1}$ of $\alpha$-ketoglutarate and $2.4 \mathrm{~g} \mathrm{~L}^{-1}$ of acetate were accumulated as major by-products. Although the titer of $\alpha$-ketoglutarate was reduced, the yield of $\alpha$-ketoglutarate was not significantly decreased ( 0.11 versus $0.13 \mathrm{~g} / \mathrm{g}$ total sugars). The concentration of fumarate was $0.15 \mathrm{~g} \mathrm{~L}^{-1}$ and that of other organic acids was less than $0.1 \mathrm{~g} \mathrm{~L}^{-1}$. Other sugars (not completely hydrolyzed disaccharides and other monosaccharides) generated during enzymatic hydrolysis might be one reason for the increased succinate yield, although they were not identified. The main reason could be the presence of citric acid/sodium citrate in the medium (the citric acid concentration in CGXIIB was about $22.1 \mathrm{~g} \mathrm{~L}^{-1}$ ), which was used as the enzyme buffer during the preparation of corn stalk hydrolysate. After cultivation for $22.5 \mathrm{~h}, 12.4 \mathrm{~g} \mathrm{~L}^{-1}$ of citric acid $(64.5 \mathrm{mM})$ were consumed for succinate production, which simulated a higher succinate yield from total sugar. As shown in Fig. 1, the carbon flux supposed to flow to the oxidative branch of the TCA cycle could be saved by consuming citrate to produce $\alpha$-ketoglutarate and NADPH. The succinate yield based on the total sugars was, therefore, increased; however, to be more accurate, the succinate yield was recalculated as $0.87 \mathrm{~g} / \mathrm{g}$ total substrates, based on the consumed glucose, xylose, and citrate.

As far as we know, $98.6 \mathrm{~g} \mathrm{~L}^{-1}$ succinate is the highest ever reported titer obtained from non-food lignocellulosic hydrolysate (Table 5), and the yield and productivity were also good enough to merit further industrial scale-up.

\section{Conclusions}

In summary, an efficient two-stage fermentation process for succinate production from lignocellulosic hydrolysate, with a high titer, yield, and productivity, was achieved by metabolically engineering C. glutamicum. A titer of $98.6 \mathrm{~g} \mathrm{~L}^{-1}$ succinate was obtained with a yield of $0.87 \mathrm{~g} / \mathrm{g}$ total substrates and a succinate productivity of $4.29 \mathrm{~g} \mathrm{~L}^{-1} \mathrm{~h}^{-1}$. The excellent utilization of lignocellulosic hydrolysate and efficient succinate production under anaerobic conditions highlight 
Table 5 Production of succinate from non-food lignocellulosic biomass

\begin{tabular}{|c|c|c|c|c|c|c|}
\hline Strain & Substrate (treatment) & Conditions & Titer (g/L) & Yield (g/g) & $\begin{array}{l}\text { Productivity } \\
\left(\mathrm{g} \mathrm{L}^{-1} \mathrm{~h}^{-1}\right)\end{array}$ & References \\
\hline \multicolumn{7}{|l|}{ Actinobacillus succinogenes } \\
\hline CGMCC1593 & $\begin{array}{l}\text { Corn straw (enzymatic } \\
\text { hydrolysis) }\end{array}$ & $\begin{array}{l}\text { One stage, anaerobic } \\
\text { fed-batch fermentation, } \\
\text { complex medium }\end{array}$ & 53.2 & 0.83 & 1.21 & {$[48]$} \\
\hline CGMCC1593 & $\begin{array}{l}\text { Corn stover (enzymatic } \\
\text { hydrolysis) }\end{array}$ & $\begin{array}{l}\text { One stage, anaerobic batch } \\
\text { fermentation, complex } \\
\text { medium }\end{array}$ & 47.4 & $0.72^{\mathrm{a}}$ & 0.99 & [49] \\
\hline NJ113 & $\begin{array}{l}\text { Corn fiber (dilute acid hydroly- } \\
\text { sis) }\end{array}$ & $\begin{array}{l}\text { One stage, anaerobic batch } \\
\text { fermentation, complex } \\
\text { medium }\end{array}$ & 35.4 & 0.73 & 0.98 & {$[50]$} \\
\hline NJ113 & $\begin{array}{l}\text { Sugarcane bagasse (dilute acid } \\
\text { hydrolysis) }\end{array}$ & $\begin{array}{l}\text { One stage, anaerobic batch } \\
\text { fermentation, complex } \\
\text { medium }\end{array}$ & 23.7 & 0.79 & 0.99 & {$[51]$} \\
\hline NJ113 & $\begin{array}{l}\text { Corn fiber hydrolysate (dilute } \\
\text { acid hydrolysis) }\end{array}$ & $\begin{array}{l}\text { One stage, anaerobic batch } \\
\text { fermentation, complex } \\
\text { medium }\end{array}$ & 47.6 & 0.68 & 0.63 & [9] \\
\hline NJ113 & $\begin{array}{l}\text { Corn stover (enzymatic } \\
\text { hydrolysis) }\end{array}$ & $\begin{array}{l}\text { One stage, anaerobic batch } \\
\text { fermentation, complex } \\
\text { medium }\end{array}$ & 56.4 & 0.73 & 1.08 & {$[52]$} \\
\hline $130 Z$ & $\begin{array}{l}\text { Corn stover (dilute acid } \\
\text { hydrolysis, deacetylation) }\end{array}$ & $\begin{array}{l}\text { One stage, anaerobic continu- } \\
\text { ous fermentation, complex } \\
\text { medium }\end{array}$ & 39.6 & 0.78 & 1.77 & {$[53]$} \\
\hline $130 Z$ & $\begin{array}{l}\text { Corn stover (dilute acid } \\
\text { hydrolysis, deacetylation) }\end{array}$ & $\begin{array}{l}\text { One stage, anaerobic batch } \\
\text { fermentation, complex } \\
\text { medium }\end{array}$ & 42.8 & 0.74 & 1.27 & {$[54]$} \\
\hline $130 Z$ & $\begin{array}{l}\text { Pinewood (enzymatic } \\
\text { hydrolysis) }\end{array}$ & $\begin{array}{l}\text { One stage, anaerobic batch } \\
\text { fermentation, complex } \\
\text { medium }\end{array}$ & 20.7 & 0.65 & 0.90 & {$[55]$} \\
\hline CIP 106512 & $\begin{array}{l}\text { Sugarcane bagasse hemicellu- } \\
\text { lose (dilute acid hydrolysis) }\end{array}$ & $\begin{array}{l}\text { One stage, anaerobic batch } \\
\text { fermentation, complex } \\
\text { medium }\end{array}$ & 22.5 & 0.43 & 1.01 & {$[56]$} \\
\hline \multicolumn{7}{|l|}{ Escherichia coli } \\
\hline BA204 & $\begin{array}{l}\text { Corn stalk (dilute acid hydroly- } \\
\text { sis) }\end{array}$ & $\begin{array}{l}\text { Two stages, aerobic culture } \\
\text { of biomass and anaerobic } \\
\text { batch fermentation, com- } \\
\text { plex medium }\end{array}$ & 11.1 & 1.02 & 0.70 & [7] \\
\hline AFP 184 & $\begin{array}{l}\text { Spruce softwood (dilute acid } \\
\text { hydrolysis) }\end{array}$ & $\begin{array}{l}\text { Two stages, aerobic culture } \\
\text { of biomass and anaerobic } \\
\text { batch fermentation, com- } \\
\text { plex medium }\end{array}$ & 42.2 & 0.72 & 0.78 & {$[57]$} \\
\hline SD121 & $\begin{array}{l}\text { Corn stalk (enzymatic hydroly- } \\
\text { sis) }\end{array}$ & $\begin{array}{l}\text { Two stages, aerobic culture } \\
\text { of biomass and anaerobic } \\
\text { batch fermentation, com- } \\
\text { plex medium }\end{array}$ & 57.8 & 0.87 & 0.96 & {$[8]$} \\
\hline BA305 & $\begin{array}{l}\text { Sugarcane bagasse (enzymatic } \\
\text { hydrolysis) }\end{array}$ & $\begin{array}{l}\text { Two-stages, aerobic culture } \\
\text { of biomass and anaerobic } \\
\text { batch fermentation, Cell- } \\
\text { recycling repeated fermen- } \\
\text { tation, minimal medium }\end{array}$ & $83^{b}$ & 0.87 & 2.31 & {$[10]$} \\
\hline BA305 & $\begin{array}{l}\text { Sugarcane bagasse (not } \\
\text { mentioned) }\end{array}$ & $\begin{array}{l}\text { One stage, anaerobic } \\
\text { fed-batch fermentation, } \\
\text { complex medium }\end{array}$ & 39.3 & 0.97 & 0.33 & {$[58]$} \\
\hline DC1515 & $\begin{array}{l}\text { Corn stalk (enzymatic hydroly- } \\
\text { sis) }\end{array}$ & $\begin{array}{l}\text { One stage, anaerobic batch } \\
\text { fermentation, complex } \\
\text { medium }\end{array}$ & 38.6 & 0.39 & 0.80 & [59] \\
\hline $\begin{array}{l}\text { Anaerobiospirillum succinicip- } \\
\text { roducens }\end{array}$ & $\begin{array}{l}\text { Oak wood (enzymatic } \\
\text { hydrolysis) }\end{array}$ & $\begin{array}{l}\text { One stage, anaerobic batch } \\
\text { fermentation, complex } \\
\text { medium }\end{array}$ & 24 & 0.88 & 0.75 & {$[60]$} \\
\hline
\end{tabular}


Table 5 (continued)

\begin{tabular}{|c|c|c|c|c|c|c|}
\hline Strain & Substrate (treatment) & Conditions & Titer (g/L) & Yield (g/g) & $\begin{array}{l}\text { Productivity } \\
\left(\mathrm{g} \mathrm{L}^{-1} \mathrm{~h}^{-1}\right)\end{array}$ & References \\
\hline $\begin{array}{l}\text { Mannheimia succiniciprodu- } \\
\text { cens }\end{array}$ & $\begin{array}{l}\text { Oak wood (enzymatic } \\
\text { hydrolysis) }\end{array}$ & $\begin{array}{l}\text { One stage, anaerobic batch } \\
\text { fermentation, complex } \\
\text { medium }\end{array}$ & 11.7 & 0.56 & 1.17 & {$[61]$} \\
\hline Basfia succiniciproducens & $\begin{array}{l}\text { Corn stover (dilute acid } \\
\text { hydrolysis) }\end{array}$ & $\begin{array}{l}\text { One stage, anaerobic batch } \\
\text { fermentation, complex } \\
\text { medium }\end{array}$ & 30 & 0.69 & 0.43 & {$[62]$} \\
\hline Corynebacterium crenatum & $\begin{array}{l}\text { Wheat bran (dilute acid } \\
\text { hydrolysis) }\end{array}$ & $\begin{array}{l}\text { Two stages, aerobic culture } \\
\text { of biomass and anaerobic } \\
\text { batch fermentation, Cell- } \\
\text { recycling repeated fermen- } \\
\text { tation, minimal medium }\end{array}$ & 43.6 & 0.59 & 4.36 & {$[63]$} \\
\hline \multicolumn{7}{|l|}{ Corynebacterium glutamicum } \\
\hline NC-2 & $\begin{array}{l}\text { Corn Cob (dilute acid hydroly- } \\
\text { sis) }\end{array}$ & $\begin{array}{l}\text { Two-stage, aerobic culture } \\
\text { of biomass and anaerobic } \\
\text { batch fermentation, minimal } \\
\text { medium }\end{array}$ & 40.8 & 0.69 & 0.85 & {$[18]$} \\
\hline CGS5 & $\begin{array}{l}\text { Corn stalk (enzymatic hydroly- } \\
\text { sis) }\end{array}$ & $\begin{array}{l}\text { Two-stage, aerobic culture } \\
\text { of biomass and anaerobic } \\
\text { batch fermentation, minimal } \\
\text { medium }\end{array}$ & 98.6 & $0.87^{c}$ & 4.29 & This study \\
\hline
\end{tabular}

a This yield was defined as the amount of succinic acid produced per substrate consumed

b The titer of $83 \mathrm{~g} \mathrm{~L}^{-1}$ was calculated by summing up the titers of three repetitive fermentations

c This yield was calculated based on the consumed glucose, xylose, and citrate

C. glutamicum, which is a biosafety level 1 microorganism, as a promising chassis for the lignocellulosic biorefinery.

\section{Additional file}

Additional file 1: Table S1. Primers used in this study.

\section{Authors' contributions}

YM, GL, TC, and ZW designed the experiments. YM, GL, ZsC, and RT performed the experiments; YM, ZsC, ZzC, and TC wrote the manuscript; TC, YT and ZW participated in the design of the study and helped to revise the manuscript; ZW, TC, and XZ supervised the work. All authors read and approved the final manuscript.

\section{Author details}

${ }^{1}$ Key Laboratory of Systems Bioengineering (Ministry of Education), SynBio Research Platform, Collaborative Innovation Center of Chemical Science and Engineering (Tianjin), School of Chemical Engineering and Technology, Tianjin University, Tianjin 300072, China. ${ }^{2}$ Key Laboratory of Fermentation Engineering, Ministry of Education, Hubei University of Technology, Wuhan 430068, China.

\section{Competing interests}

The authors declare that they have no competing interests.

\section{Availability of data and materials}

The materials and data used and/or analyzed during the current study are available from the corresponding author on reasonable request.

\section{Consent for publication}

Not applicable.
Ethics approval and consent to participate Not applicable.

\section{Funding}

This work was supported by the National Natural Science Foundation of China (NSFC-21390201, NSFC-21576200, NSFC-21621004) and the Natural Science Foundation of Tianjin (No. 15JCQNJC06000).

\section{Publisher's Note}

Springer Nature remains neutral with regard to jurisdictional claims in published maps and institutional affiliations.

Received: 31 October 2017 Accepted: 24 March 2018

Published online: 04 April 2018

\section{References}

1. Werpy T, Petersen GE. Top value added chemicals from biomass. Washington, D.C: US Department of Energy; 2004.

2. McKinlay JB, Vieille C, Zeikus JG. Prospects for a bio-based succinate industry. Appl Microbiol Biotechnol. 2007;76:727-40.

3. Choi S, Song CW, Shin JH, Lee SY. Biorefineries for the production of top building block chemicals and their derivatives. Metab Eng. 2015:28:223-39.

4. Ahn JH, Jang Y-S, Lee SY. Production of succinic acid by metabolically engineered microorganisms. Curr Opin Biotechnol. 2016;42:54-66.

5. Chung SC, Park JS, Yun J, Park JH. Improvement of succinate production by release of end-product inhibition in Corynebacterium glutamicum. Metab Eng. 2017:40:157-64.

6. Thuy NTH, Kongkaew A, Flood A, Boontawan A. Fermentation and crystallization of succinic acid from Actinobacillus succinogenes ATCC55618 using fresh cassava root as the main substrate. Bioresour Technol. 2017:233:342-52

7. Liu R, Liang L, Chen K, Ma J, Jiang M, Wei P, Ouyang P. Fermentation of xylose to succinate by enhancement of ATP supply in metabolically engineered Escherichia coli. Appl Microbiol Biotechnol. 2012;94:959-68. 
8. Wang D, Li Q, Yang M, Zhang Y, Su Z, Xing J. Efficient production of succinic acid from corn stalk hydrolysates by a recombinant Escherichia coli with ptsG mutation. Process Biochem. 2011;46:365-71.

9. Chen KQ, Li J, Ma JF, Jiang M, Wei P, Liu ZM, Ying HJ. Succinic acid production by Actinobacillus succinogenes using hydrolysates of spent yeast cells and corn fiber. Bioresour Technol. 2011;102:1704-8.

10. Liang L, Liu R, Li F, Wu M, Chen K, Ma J, Jiang M, Wei P, Ouyang P. Repetitive succinic acid production from lignocellulose hydrolysates by enhancement of ATP supply in metabolically engineered Escherichia coli. Bioresour Technol. 2013;143:405-12.

11. Cai D, Li P, Luo Z, Qin P, Chen C, Wang Y, Wang Z, Tan T. Effect of dilute alkaline pretreatment on the conversion of different parts of corn stalk to fermentable sugars and its application in acetone-butanol-ethanol fermentation. Bioresour Technol. 2016;211:117-24.

12. Akhtar J, Idris A, Abd Aziz R. Recent advances in production of succinic acid from lignocellulosic biomass. Appl Microbiol Biotechnol. 2014;98:987-1000.

13. Okino S, Noburyu R, Suda M, Jojima T, Inui M, Yukawa H. An efficient succinic acid production process in a metabolically engineered Corynebacterium glutamicum strain. Appl Microbiol Biotechnol. 2008;81:459-64.

14. Litsanov B, Brocker M, Bott M. Toward homosuccinate fermentation: metabolic engineering of Corynebacterium glutamicum for anaerobic production of succinate from glucose and formate. Appl Environ Microbiol. 2012;78:3325-37.

15. Zhu N, Xia H, Yang J, Zhao X, Chen T. Improved succinate production in Corynebacterium glutamicum by engineering glyoxylate pathway and succinate export system. Biotechnol Lett. 2014;36:553-60.

16. Xu H, Zhou Z, Wang C, Chen Z, Cai H. Enhanced succinic acid production in Corynebacterium glutamicum with increasing the available NADH supply and glucose consumption rate by decreasing H+-ATPase activity. Biotechnol Lett. 2016;38(7):1181-6.

17. Shi X, Chen Y, Ren H, Liu D, Zhao T, Zhao N, Ying H. Economically enhanced succinic acid fermentation from cassava bagasse hydrolysate using Corynebacterium glutamicum immobilized in porous polyurethane filler. Bioresour Technol. 2014;174:190-7.

18. Wang C, Zhang H, Cai H, Zhou Z, Chen Y, Chen Y, Ouyang P. Succinic acid production from corn cob hydrolysates by genetically engineered Corynebacterium glutamicum. Appl Biochem Biotechnol. 2013;172(1):340-50.

19. Kawaguchi $H$, Vertes AA, Okino S, Inui M, Yukawa H. Engineering of a xylose metabolic pathway in Corynebacterium glutamicum. Appl Environ Microbiol. 2006;72:3418-28.

20. Sasaki M, Jojima T, Inui M, Yukawa H. Simultaneous utilization of D-cellobiose, D-glucose, and D-xylose by recombinant Corynebacterium glutamicum under oxygen-deprived conditions. Appl Microbiol Biotechnol. 2008;81:691-9.

21. Yim SS, Choi JW, Lee SH, Jeong KJ. Modular optimization of a hemicellulose-utilizing pathway in Corynebacterium glutamicum for consolidated bioprocessing of hemicellulosic biomass. ACS Synth Biol. 2016:5:334-43.

22. Kang MK, Lee J, Um Y, Lee TS, Bott M, Park SJ, Woo HM. Synthetic biology platform of CoryneBrick vectors for gene expression in Corynebacterium glutamicum and its application to xylose utilization. Appl Microbiol Biotechnol. 2014:98:5991-6002.

23. Meiswinkel TM, Gopinath V, Lindner SN, Nampoothiri KM, Wendisch VF. Accelerated pentose utilization by Corynebacterium glutamicum for accelerated production of lysine, glutamate, ornithine and putrescine. Microb Biotechnol. 2013;6:131-40.

24. Sasaki M, Jojima T, Kawaguchi H, Inui M, Yukawa H. Engineering of pentose transport in Corynebacterium glutamicum to improve simultaneous utilization of mixed sugars. Appl Microbiol Biotechnol. 2009:85:105-15.

25. Sasaki M, Jojima T, Inui M, Yukawa H. Xylitol production by recombinant Corynebacterium glutamicum under oxygen deprivation. Appl Microbiol Biotechnol. 2010;86:1057-66.

26. Chen Z, Huang J, Wu Y, Wu W, Zhang Y, Liu D. Metabolic engineering of Corynebacterium glutamicum for the production of 3-hydroxypropionic acid from glucose and xylose. Metab Eng. 2017;39:151-8.

27. Kim H, Lee HS, Park H, Lee D-H, Boles E, Chung D, Park Y-C. Enhanced production of xylitol from xylose by expression of Bacillus subtilis arabinose: $\mathrm{H}+$ symporter and scheffersomyces stipitis xylose reductase in recombinant Saccharomyces cerevisiae. Enzyme Microl Technol. 2017;107:7-14.

28. Jo S, Yoon J, Lee SM, Um Y, Han SO, Woo HM. Modular pathway engineering of Corynebacterium glutamicum to improve xylose utilization and succinate production. J Biotechnol. 2017;258:69-78.

29. Radek A, Krumbach K, Gätgens J, Wendisch VF, Wiechert W, Bott M, Noack $\mathrm{S}$, Marienhagen J. Engineering of Corynebacterium glutamicum for minimized carbon loss during utilization of D-xylose containing substrates. J Biotechnol. 2014;192(Part A):156-60.

30. Radek A, Tenhaef N, Müller M, Brüsseler C, Wiechert W, Marienhagen J, Polen T, Noack S. Miniaturized and automated adaptive laboratory evolution: Evolving Corynebacterium glutamicum towards an improved D-xylose utilization. Bioresour Technol. 2017;245(Part B):1377-85.

31. Zhu N, Xia H, Wang Z, Zhao X, Chen T. Engineering of acetate recycling and citrate synthase to improve aerobic succinate production in Corynebacterium glutamicum. PLoS ONE. 2013;8:e60659.

32. Quan J, Tian J. Circular polymerase extension cloning for high-throughput cloning of complex and combinatorial DNA libraries. Nat Protoc. 2011;6:242-51.

33. Eggeling L, Bott M. Handbook of Corynebacterium glutamicum. Boca Raton: CRC Press; 2005

34. Chen T, Zhu N, Xia H. Aerobic production of succinate from arabinose by metabolically engineered Corynebacterium glutamicum. Bioresour Technol. 2014;151:411-4.

35. Zheng Z, Chen T, Zhao M, Wang Z, Zhao X. Engineering Escherichia coli for succinate production from hemicellulose via consolidated bioprocessing. Microb Cell Fact. 2012;11:37.

36. Zhang F, Li J, Liu H, Liang Q, Qi Q. ATP-based ratio regulation of glucose and xylose improved succinate production. PLOS ONE. 2016;11(6):e0157775.

37. Inui M, Murakami S, Okino S, Kawaguchi H, Vertes AA, Yukawa H. Metabolic analysis of Corynebacterium glutamicum during lactate and succinate productions under oxygen deprivation conditions. J Mol Microb Biotechnol. 2004;7:182-96.

38. Genda T, Nakamatsu T, Ozaki H. Purification and characterization of malate dehydrogenase from Corynebacterium glutamicum. J Biosci Bioeng. 2003;95:562-6.

39. Matsushika A, Goshima T, Fujii T, Inoue H, Sawayama S, Yano S. Characterization of non-oxidative transaldolase and transketolase enzymes in the pentose phosphate pathway with regard to xylose utilization by recombinant Saccharomyces cerevisiae. Enzyme Microl Technol. 2012;51:16-25.

40. Zhou H, Cheng JS, Wang BL, Fink GR, Stephanopoulos G. Xylose isomerase overexpression along with engineering of the pentose phosphate pathway and evolutionary engineering enable rapid xylose utilization and ethanol production by Saccharomyces cerevisiae. Metab Eng. 2012;14:611-22.

41. Jojima T, Omumasaba CA, Inui M, Yukawa H. Sugar transporters in efficient utilization of mixed sugar substrates: current knowledge and outlook. Appl Microbiol Biotechnol. 2010;85:471-80.

42. Kawaguchi $H$, Sasaki M, Vertes $A A$, Inui M, Yukawa H. Engineering of an L-arabinose metabolic pathway in Corynebacterium glutamicum. Appl Microbiol Biotechnol. 2008;77:1053-62.

43. Chen T, Liu WX, Fu J, Zhang B, Tang YJ. Engineering Bacillus subtilis for acetoin production from glucose and xylose mixtures. J Biotechnol. 2013;168:499-505.

44. Rados D, Turner DL, Fonseca LL, Carvalho AL, Blombach B, Eikmanns $B$ J, Neves AR, Santos $\mathrm{H}$. Carbon flux analysis by ${ }^{13} \mathrm{C}$ nuclear magnetic resonance to determine the effect of $\mathrm{CO}_{2}$ on anaerobic succinate production by Corynebacterium glutamicum. Appl Environ Microbiol. 2014:80:3015-24.

45. Sakai S, Tsuchida Y, Nakamoto H, Okino S, Ichihashi O, Kawaguchi H, Watanabe T, Inui M, Yukawa H. Effect of lignocellulose-derived inhibitors on growth of and ethanol production by growth-arrested Corynebacterium glutamicum R. Appl Environ Microbiol. 2007;73:2349-53.

46. Xu HT, Wang C, Zhou ZH, Chen ZJ, Cai H. Effects of lignocellulose-derived inhibitors on growth and succinic acid accumulation by Corynebacterium glutamicum. Bioprocess Biosyst Eng. 2015;20:744-52.

47. Rodrigues AC, Haven M $\varnothing$, Lindedam J, Felby C, Gama M. Celluclast and Cellic ${ }^{\circledR}$ CTec2: saccharification/fermentation of wheat straw, solid-liquid partition and potential of enzyme recycling by alkaline washing. Enzyme Microl Technol. 2015:79:70-7. 
48. Zheng P, Dong JJ, Sun ZH, Ni Y, Fang L. Fermentative production of succinic acid from straw hydrolysate by Actinobacillus succinogenes. Bioresour Technol. 2009;100:2425-9.

49. Zheng P, Fang L, Xu Y, Dong J-J, Ni Y, Sun Z-H. Succinic acid production from corn stover by simultaneous saccharification and fermentation using Actinobacillus succinogenes. Bioresour Technol. 2010;101:7889-94.

50. Chen $\mathrm{K}$, Jiang $M$, Wei $P$, Yao J, Wu H. Succinic acid production from acid hydrolysate of corn fiber by Actinobacillus succinogenes. Appl Biochem Biotechnol. 2010;160:477-85.

51. Xi YL, Dai WY, Xu R, Zhang JH, Chen KQ, Jiang M, Wei P, Ouyang PK. Ultrasonic pretreatment and acid hydrolysis of sugarcane bagasse for succinic acid production using Actinobacillus succinogenes. Bioprocess Biosyst Eng. 2013:36:1779-85

52. Li J, Zheng XY, Fang XJ, Liu SW, Chen KQ, Jiang M, Wei P, Ouyang PK. A complete industrial system for economical succinic acid production by Actinobacillus succinogenes. Bioresour Technol. 2011;102:6147-52.

53. Bradfield MF, Mohagheghi A, Salvachúa D, Smith H, Black BA, Dowe N, Beckham GT, Nicol W. Continuous succinic acid production by Actinobacillus succinogenes on xylose-enriched hydrolysate. Biotechnol Biofuels. 2015;8:181.

54. Salvachúa D, Mohagheghi A, Smith H, Bradfield MF, Nicol W, Black BA, Biddy MJ, Dowe N, Beckham GT. Succinic acid production on xyloseenriched biorefinery streams by Actinobacillus succinogenes in batch fermentation. Biotechnol Biofuels. 2016:9:28.

55. Wang C, Yan D, Li Q, Sun W, Xing J. Ionic liquid pretreatment to increase succinic acid production from lignocellulosic biomass. Bioresour Technol. 2014;172:283-9.
56. Borges ER, Pereira N. Succinic acid production from sugarcane bagasse hemicellulose hydrolysate by Actinobacillus succinogenes. J Ind Microbiol Biotechnol. 2011;38:1001-11.

57. Hodge DB. Detoxification requirements for bioconversion of softwood dilute acid hydrolyzates to succinic acid. Enzyme Microl Technol. 2009;44:309-16.

58. Liu R, Liang L, Li F, Wu M, Chen K, Ma J, Jiang M, Wei P, Ouyang P. Efficient succinic acid production from lignocellulosic biomass by simultaneous utilization of glucose and xylose in engineered Escherichia coli. Bioresour Technol. 2013;149:84-91.

59. Wu D, Li Q, Wang D, Dong Y. Enzymatic hydrolysis and succinic acid fermentation from steam-exploded corn stalk at high solid concentration by recombinant Escherichia coli. Appl Biochem Biotechnol. 2013;170:1942-9.

60. Lee PC, Lee SY, Hong SH, Chang HN, Park SC. Biological conversion of wood hydrolysate to succinic acid by Anaerobiospirillum succiniciproducens. Biotechnol Lett. 2003;25:111.

61. Kim DY, Yim SC, Lee PC, Lee WG, Sang YL, Chang HN. Batch and continuous fermentation of succinic acid from wood hydrolysate by Mannheimia succiniciproducens MBEL55E. Enzyme Microl Technol. 2004:35:648-53.

62. Salvachúa D, Smith H, John PCS, Mohagheghi A, Peterson DJ, Black BA, Dowe N, Beckham GT. Succinic acid production from lignocellulosic hydrolysate by Basfia succiniciproducens. Bioresour Technol. 2016;214:558-66

63. Chen X, Jiang S, Li X, Pan L, Zheng Z, Luo S. Production of succinic acid and lactic acid by Corynebacterium crenatum under anaerobic conditions. Ann Microbiol. 2013;63:39-44.
Ready to submit your research? Choose BMC and benefit from:

- fast, convenient online submission

- thorough peer review by experienced researchers in your field

- rapid publication on acceptance

- support for research data, including large and complex data types

- gold Open Access which fosters wider collaboration and increased citations

- maximum visibility for your research: over $100 \mathrm{M}$ website views per year

At $\mathrm{BMC}$, research is always in progress.

Learn more biomedcentral.com/submissions 